FRAN BARBER

\title{
RELIGIOUS VILIFICATION LAWS IN NEW ZEALAND: SHOULD THE FREEDOM OF EXPRESSION BE TAKEN AS GOSPEL?
}

LAWS 520: Censorship and the Freedom of Expression

\author{
Faculty of Law
}

Victoria University of Wellington

2014 


\section{Abstract}

With ever-increasing multiculturalism and diversity within New Zealand, this paper explores the potential for religious vilification laws to be passed in order to promote community tolerance. New Zealand's Human Rights Act 1993 includes both civil and criminal offences for the incitement of hostility on the grounds of race. There is no commensurate provision protecting religion. This paper considers the harm that religious vilification laws seek to remedy, and whether their efficacy in preventing this harm is proportionate to the incursion upon the freedom of expression. Ultimately, it suggests that while there are real harms associated with religious hate speech, the adversarial legal system is a flawed instrument through which to deal with it.

Key words: religious vilification, Human Rights Act 1993, freedom of expression, Islamic Council of Victoria $v$ Catch the Fire Ministries, Racial and Religious Tolerance Act 2001 (Vic). 


\section{Table of Contents}

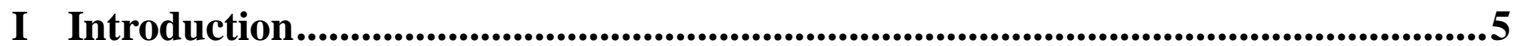

II Religion in New Zealand ...............................................................................................6

III An introduction to religious vilification laws..................................................7

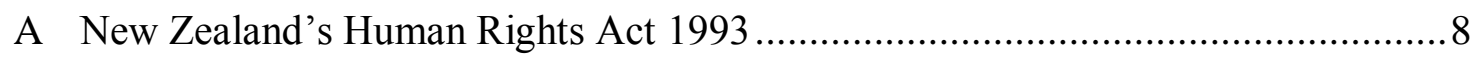

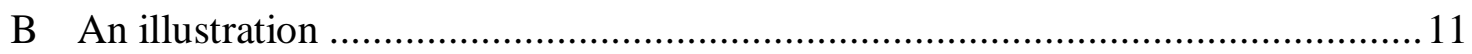

IV The freedom of expression and the New Zealand Bill of Rights Act 1990.........11

V The harm of vilification........................................................................................13

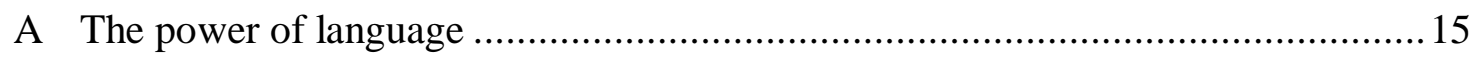

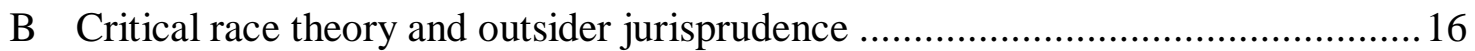

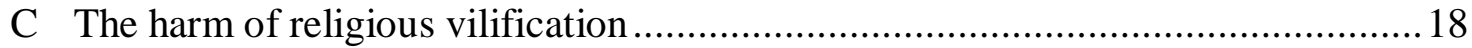

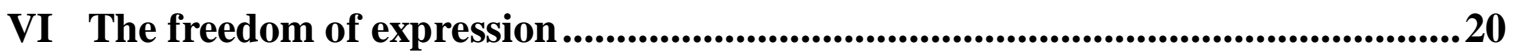

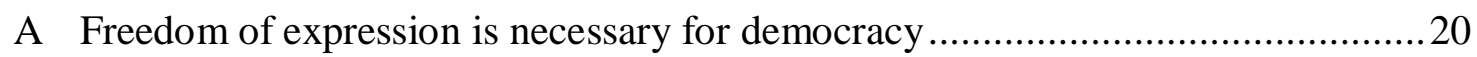

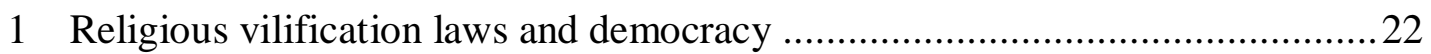

B Freedom of expression is necessary to the discovery of truth .............................23

1 Religious vilification laws and the search for truth .......................................25

C Freedom of expression is necessary for human self-fulfilment ...........................28

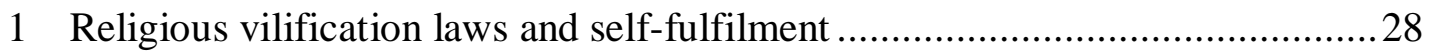

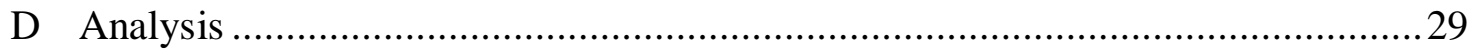

VII The experience in Victoria, Australia ...................................................................31

A The Racial and Religious Tolerance Act 2001 (Vic) ............................................. 31

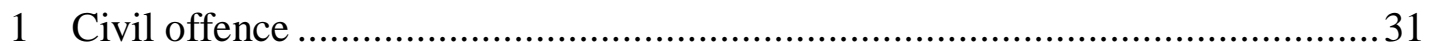

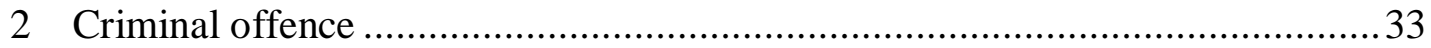

B Islamic Council of Victoria v Catch the Fire Ministries ......................................... 34

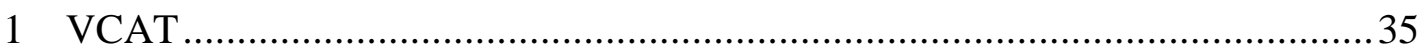

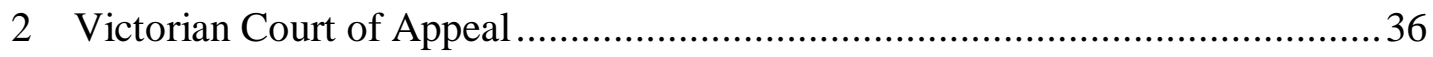

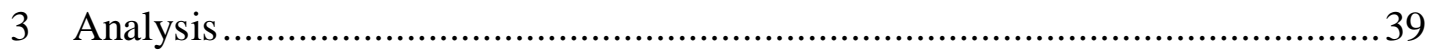

C The problems with Victoria's religious vilification law …….................................39

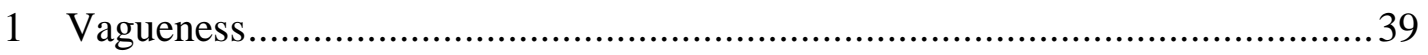

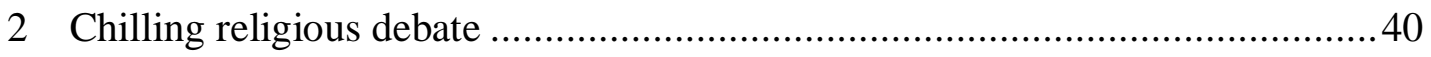

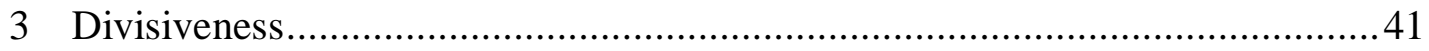

VIII The English experience......................................................................................43

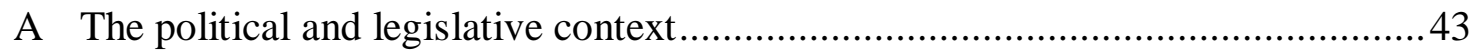

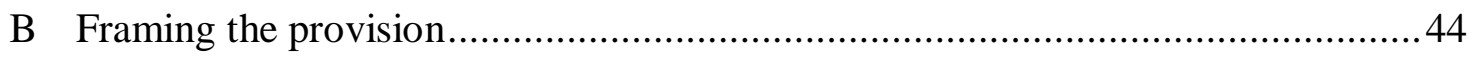

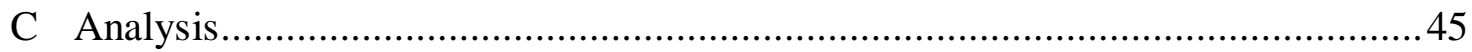


IX Is there scope for an expansion of the Human Rights Act 1993? ........................46

A Does it serve a sufficiently important purpose to justify curtailing the freedom of

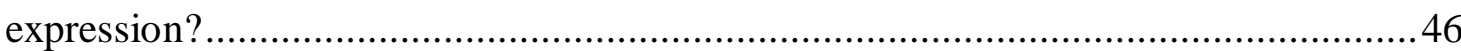

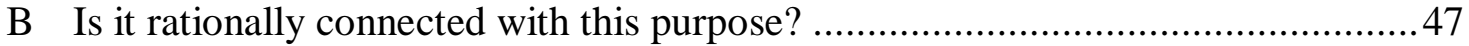

C Does it impair the freedom of expression no more than is reasonably necessary for sufficient achievement of its purpose? .........................................................47

1 Difficulties in framing a law............................................................ 47

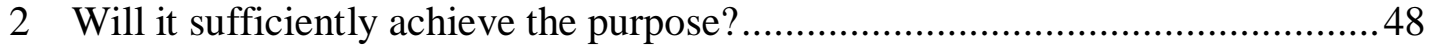

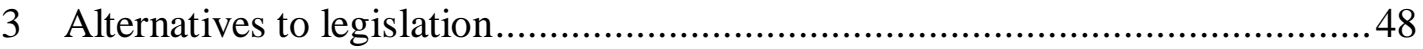

D Is it in due proportion to the importance of the objective? .............................49

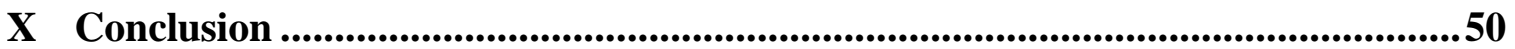

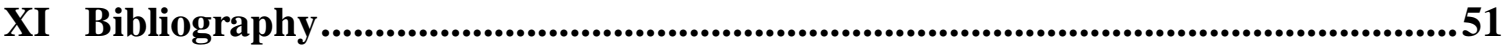

\section{Word Count}

The text of this paper (excluding abstract, table of contents, footnotes, and bibliography) comprises approximately $\mathbf{1 4 , 9 4 8}$ words. 


\section{Introduction}

The law is a powerful tool in fostering a tolerant and stable society. The legal system must respond to an increasingly multicultural, globalized world. Hate speech aimed at a particular group hinders societal cohesion. The willingness for governments to suppress racially or religiously motivated hate speech has been gauged differently throughout the world, and has given rise to a large body of scholarship discussing the legitimacy of such laws. While many jurisdictions, New Zealand included, have prohibited the incitement of racial hostility or hatred, there has been a recent movement to extend this to religious incitement also. Should New Zealand follow England, Canada and certain Australian states in prohibiting the incitement of religious hatred?

This implicates the freedom of expression, a fundamental tenet of western liberal democracies. Individuals must be free to express religious ideas that "offend, shock or disturb the State or any sector of the population". ${ }^{1}$ The right only becomes meaningful when it protects something that is contested. ${ }^{2}$ There is no need protect the freedom to express popular ideas. However, even the most ardent liberalists do not deny that this right must have limits. Negotiating limits requires philosophical and legal arguments - at its core, free expression concerns the extent to which the state may legitimately impinge on individual autonomy. Yet, debating in abstract terms only takes us so far. Freedom of expression discussions may tend to disconnect from each jurisdiction's social and cultural milieu. ${ }^{3}$ The context is important.

Underscored by the New Zealand Bill of Rights Act 1991 (BORA), this paper will inquire into whether religious vilification laws are a proportionate limitation on the freedom of expression. After looking at the place of religion in New Zealand in Part II, Part III introduces the issue of religious vilification laws in New Zealand. The BORA rights are discussed in Part IV. Part V considers the purpose of religious vilification laws in protecting against harm. Drawing on critical race theory, it suggests that protecting people from harm is a worthy aim; vilification can result in real injury to its targets. However, this must be weighed against the impact that religious vilification laws have on the core rationales for the freedom of expression, as is explored in Part VI. Part VII turns

${ }^{1}$ Handyside v UK [1976] ECHR 5 (ECHR) at [49]; cited in Living Word Distributors Ltd v Human Rights Action Group (Wellington) [2000] 3 NZLR 570 (CA).

${ }^{2}$ Grant Huscroft "Defamation, Racial Disharmony, and Freedom of Expression" in Grant Huscroft and Paul Rishworth (eds) Rights and Freedoms (Brooker's Ltd, Wellington, 1995) 171 at 192.

${ }^{3}$ Huscroft, above n 2, at 175. 
to look at the issues that Australia and England have had with religious vilification laws in practice. Finally, Part VIII discusses the proportionality of religious vilification laws in New Zealand, considering its social context.

Ultimately, this paper will conclude that legislative intervention in this manner is unnecessary. Although the incursion on freedom of expression is slim, articulating a law to adequately balance the competing interests creates more problems than it solves. There are non-law mechanisms - education and community programmes - that can better foster tolerance than the use of the adversarial legal system.

\section{Religion in New Zealand}

New Zealand's relative cultural homogeneity (within official anglocentric discourses, at least) has led the country to be built upon what Rishworth describes as a set of "comfortable, and for the most part accurate, assumptions about a shared set of beliefs in the New Zealand community."4 New Zealand has never claimed an established religion, but adopted instead a generic, de facto Christian tilt. Religious equality was emphasised within state discourses from the outset."

However, this Christian influence has more recently been overtaken by a drive towards secularisation. ${ }^{6}$ The appropriateness of using a Christian prayer to open Parliament sitting days, or having Christian teaching in state schools has increasingly been questioned. Yet, multiculturalism and religious diversity have ensured that the state's response to religious concerns has remained a matter of public significance. Between 2006 and 2013, the percentage of the population purporting to be non-religious increased from 34.6 per cent to 41.9 per cent. The number of those affiliated with Christianity decreased, whereas the size of the Sikh, Hindu and Muslim communities increased by 101.9, 36.9 and 27.9 per cent respectively. ${ }^{7}$

Therefore, religion occupies an interesting new position within New Zealand's social fabric. The increase of secularism both in the public and private sphere has the potential

${ }^{4}$ Paul Rishworth "The Religion Clauses of the New Zealand Bill of Rights" (2007) NZLR 631 at 632.

${ }^{5}$ Rex J Ahdar "Reflections on the Path of Religion-State Relations in New Zealand" (2006) 3 BYU Law Review 619 at 623, 627.

${ }^{6}$ At 621.

7 “2013 QuickStats About Culture and Identity" (April 2013) Statistics New Zealand <http://www.stats.govt.nz>. 
to exacerbate tensions, especially as the "liberalising agenda of secularisation sharpens [religious] groups' differences with mainstream society". ${ }^{8}$ This is especially so considering the vocal opposition of a number of religious groups to matters such as abortion, euthanasia and homosexual marriage.

New Zealand is no longer as insulated from international religious tensions as it may have been in the past. For instance, when the Danish newspaper Jyllands-Posten published offensive caricatures of the Prophet Mohammed in 2006, New Zealand's Dominion Post and the Christchurch Press decided to publish the cartoons also. In response, 800 protestors marched down Auckland's Queen Street. ${ }^{9}$ Religious extremism in current geopolitics further ensures that religious differences remain in popular discourse. As more diverse religious ideologies are reflected in New Zealand's societal make-up, the Human Rights Commission has recognised that it is likely that " $[\mathrm{t}] \mathrm{hese}$ deeply held differences will likely lead to future tensions within and between faith communities, and between faith communities and those who hold non-religious values."10 Legislation may aid in reducing the likelihood of these tensions flaring.

\section{An introduction to religious vilification laws}

A number of countries have legislated to prohibit the incitement of hatred on the grounds of religion. This paper will refer to these as "religious vilification laws". It is important to distinguish between these and laws such as Denmark's, which create an offence for any person who ${ }^{11}$

publicly or with the intention of wider dissemination, makes a statement or imparts other information by which a group of people are threatened, insulted or degraded on account of their race, color, national or ethnic origin, religion or sexual inclination.

While many of the objections to, and arguments for these laws are the same, the Danish example prohibits direct offence to the recipient, rather than the fostering of hatred in a third party. This adds a problematic layer of subjectivity. Even if the touchstone is objective (whether a reasonable religious person would be "threatened, insulted, or degraded" in the circumstances) certain religious groups are more sensitive than others.

\footnotetext{
${ }^{8}$ Rishworth, above n 4, at 633.

${ }^{9}$ Errol Kiong and Jon Stokes "NZ embassy alert over cartoon row" (6 February 2006) New Zealand Herald <http://www.nzherald.co.nz>.

${ }^{10}$ Human Rights Commission Religious Diversity in Aotearoa New Zealand: Statement on Religious Diversity (2 ${ }^{\text {nd }}$ ed, August 2009) at 10.

${ }^{11}$ Danish Criminal Code, s 266.
} 
Whether it is possible to apply this law even-handedly without privileging certain groups is doubtful.

In New Zealand, the more pertinent issue is whether its existing racial vilification laws should be extended to religious vilification also. In 2006, England passed the Racial and Religious Hatred Act, creating a criminal offence for "us[ing] threatening words or behaviour, or display[ing] any written material which is threatening... if he intends thereby to stir up religious hatred."12

Three Australian states legislate for religious vilification also. Victoria and Queensland ${ }^{13}$ have materially similar civil and criminal provisions for inciting religious hatred. Tasmania's legislation provides a civil offence for inciting religious hatred, but has no criminal provision. ${ }^{14}$ Victoria's Racial and Religious Tolerance Act 2001 has given rise to the most discussion, stating that: ${ }^{15}$

A person must not, on the ground of the religious belief or activity of another person or class of persons, engage in conduct that incites hatred against, serious contempt for, or revulsion or severe ridicule of, that other person or class of persons.

\section{A New Zealand's Human Rights Act 1993}

In contrast, New Zealand's human rights framework only prohibits the incitement of racial hostility or contempt. Section 61 of the Human Rights Act 1993 (HRA) provides that it is unlawful for any person

(a) to publish or distribute written matter which is threatening, abusive, or insulting, or to broadcast by means of radio or television words which are threatening, abusive, or insulting; or

(b) to use in any public place as defined in section 2(1) of the Summary Offences Act 1981, or within the hearing of persons in any such public place, or at any meeting to which the public are invited or have access, words which are threatening, abusive, or insulting; or

(c) to use in any place words which are threatening, abusive, or insulting if the person using the words knew or ought to have known that the words were

${ }^{12}$ Racial and Religious Hatred Act 2006 (UK), s 29B.

13 Anti-Discrimination Amendment Act 2001 (Qld), ss 124A and 131A.

${ }^{14}$ Anti-Discrimination Act 1998 (Tas), s 19.

${ }^{15}$ Racial and Religious Tolerance Act 2001 (Vic), s 8(1). 
reasonably likely to be published in a newspaper, magazine, or periodical or broadcast by means of radio or television,-

being matter or words likely to excite hostility against or bring into contempt any group of persons in or who may be coming to New Zealand on the ground of the colour, race, or ethnic or national origins of that group of persons.

No intention is required, so long as "threatening, abusive or insulting" words or material is used in public circumstances, where it is likely to invoke the prohibited reaction in the audience. The audience need not actually be incited to hostility or contempt. An audience may dismiss the behaviour as outlandish and bigoted, yet it may still fall within the scope of the Act.

If $\mathrm{s} 61$ is breached, the aggrieved person may complain to the Human Rights Commission. The HRA establishes a flexible dispute resolution process, which focuses on the prompt resolution of issues by the parties themselves. The Commission facilitates dispute resolution, including mediation services, which may result in an enforceable settlement. ${ }^{16}$ Alternatively, civil proceedings arising from a complaint may be brought before the Human Rights Review Tribunal. The Tribunal has powers to provide a broad range of remedies, including damages, a declaration, or specific redress. ${ }^{17}$

In addition, section 131 of the HRA creates a criminal offence for particularly egregious behaviour. Any person who

with intent to excite hostility or ill-will against, or bring into contempt or ridicule, any group of persons in New Zealand on the ground of the colour, race, or ethnic or national origins of that group of persons,-

(a) publishes or distributes written matter which is threatening, abusive, or insulting, or broadcasts by means of radio or television words which are threatening, abusive, or insulting; or

(b) uses in any public place (as defined in section 2(1) of the Summary Offences Act 1981), or within the hearing of persons in any such public place, or at any meeting to which the public are invited or have access, words which are threatening, abusive, or insulting, -

being matter or words likely to excite hostility or ill-will against, or bring into contempt or ridicule, any such group of persons in New Zealand on the ground of the colour, race, or ethnic or national origins of that group of persons.

\footnotetext{
${ }^{16}$ See Human Rights Act 1993, Part 3.

${ }^{17}$ Human Rights Act 1993, s 92I.
} 
Upon conviction, an offender is liable to up to three months' imprisonment or a fine not exceeding \$7,000. Nevertheless, this offence was not intended to be drawn upon often the Attorney-General's consent is required before a prosecution can be instituted. ${ }^{18}$

Despite legislating in this manner, New Zealand's approach to racial hatred has been minimalist. In practice, s 131 has never been used, and its predecessor under the Race Relations Act 1971 was only used once. ${ }^{19}$ Section 61 generates a number of complaints, but these usually fall short of the threshold for intervention. As the Human Rights Commission's 2013 annual report states, while comments complained about were "frequently racially offensive, they were not considered to be unlawful" under s $61 .^{20}$ "Low-level" dispute resolution was employed occasionally "to encourage greater understanding about the effect of comments which can be taken as racially offensive." 21 One might suggest that these laws have more significance in implementing New Zealand's international obligations than in providing a meaningful deterrent for the incitement of racial hostility. ${ }^{22}$ Nevertheless, this does show New Zealand's use of the legal system to condemn what is considered to be damaging racist behaviour.

If a religious law were to be created, it is most likely that it will parallel the current legislative framework. This paper proceeds on the basis that the language used in a religious vilification provision would be materially similar to that already found in the HRA.

\footnotetext{
${ }^{18}$ Section 132.

${ }^{19}$ King-Ansell v Police [1979] 2 NZLR 531 (CA).

${ }^{20}$ Human Rights Commission “Annual Report 2013” (October 2013) Human Rights Commission <www.hrc.co.nz> at 20-21.

21 At 21.

${ }^{22}$ See International Convention on the Elimination of All Forms of Racial Discrimination 660 UNTS 195 (opened for signature 21 December 1965, entered into force 4 January 1969), art 4. Section 20 of the International Covenant on Civil and Political Rights 999 UNTS 171 (opened for signature 16 December 1966, entered into force 23 March 1976), requires States Parties to prohibit "any advocacy of national, racial or religious hatred that constitutes incitement to hostility, discrimination or violence." However, New Zealand has reserved the right not to legislate further for religious hatred.
} 


\section{B An illustration}

In early 2013, Richard Prosser (a New Zealand First Member of Parliament), asserted that while not all Muslims are terrorists, "most terrorists are Muslims". In his column in the Investigate magazine, he wrote: ${ }^{23}$

If you are a young male, aged between say about 19 and about 35, and you're a Muslim, or you look like a Muslim, or you come from a Muslim country, then you are not welcome to travel on any of the West's airlines... I will not stand by while [my daughters'] rights and freedoms of other New Zealanders and Westerners, are denigrated by a sorry pack of misogynist troglodytes from Wogistan.

Ought this invoke legal sanction? Arguably, Prosser's statements exacerbate existing divisions and intolerances within society, bolstering the stereotype that Muslims are terrorists. This serves to rally and validate anti-Muslim sentiment. If these ideas take root and spread, Muslims' standing within the wider community will be degraded. These ideas are antithetical to a multicultural utopia that thrives on the equality of its citizens. Prosser's reference to Muslim countries and the racially derogatory term "Wogistan" may be sufficient to characterise his comments as based on "colour, race, or ethnic or national origins". However, his assertion that Muslims are terrorists is less an expression of racism than a derogation of Muslim people on the ground of their religious beliefs - some of which are shared with terrorists.

\section{The freedom of expression and the New Zealand Bill of Rights Act 1990}

In debating the limits of permissible expression, the freedom of expression is the necessary starting point. Any limitation or regulation of speech impinges on this freedom. The BORA expressly protects this in s 14, providing that "[e]veryone has the right to freedom of expression, including the freedom to seek, receive, and impart information and opinions of any kind in any form." This right is not absolute. Under s 5, the BORA rights and freedoms "may be subject only to such reasonable limits prescribed by law as can be demonstrably justified in a free and democratic society."

The BORA is not supreme law, and Parliament may legislate to limit rights further than permitted under s 5. Section 4 provides that a court may not decline to apply legislation on the grounds that it is inconsistent with the BORA rights. Unlike the United States, New Zealand courts are not empowered to strike down inconsistent legislation. That said,

${ }^{23}$ Kurt Bayer "NZ First MP: Ban Muslims from flights" (12 February 2013) New Zealand Herald <www.nzherald.co.nz>. 
one must assume that Parliament intends to legislate consistently with the BORA, especially considering the fundamental significance of freedom of expression to the relationship between the individual and the state.

Whether a religious vilification law should be adopted in New Zealand depends on whether such an incursion on freedom of expression is "demonstrably justified" as per s 5. The Supreme Court discussed the s 5 methodology in Hansen $v R$, and adopts the Canadian approach to the near-identical provision within the Canadian Charter of Rights and Freedoms. ${ }^{24}$ Tipping $\mathrm{J}$ frames the $R v$ Oakes approach as: ${ }^{25}$

a) does the limiting measure serve a purpose sufficiently important to justify curtailment of the right or freedom?

b) i) is the limiting measure rationally connected with its purpose?

ii) does the limiting measure impair the right or freedom no more than is reasonably necessary for sufficient achievement of its purpose?

iii) is the limit in due proportion to the importance of the objective?

As Tipping J concludes, "[w]hether a limit on a right or freedom is justified under s 5 is essentially an inquiry into whether a justified end is achieved by proportionate means." 26 This requires a balancing exercise: "whether the practical benefits to society of the limit under consideration outweigh the harm done to the individual right or freedom."27

This will also give an insight as to how the courts might interpret such a law. Under s 6 , courts are required to prefer a meaning consistent with the Bill of Rights Act rights and freedoms wherever possible. However, the prevailing approach set down by the majority in Hansen states that an enactment will only be inconsistent with these rights if the limitation goes beyond that which is demonstrably justified. The court will engage its interpretive powers only when legislation fails to protect individuals' "reasonable" rights. $^{28}$

${ }^{24} R$ v Oakes [1986] 1 SCR 103.

${ }^{25}$ Hansen v R [2007] NZSC 7, [2007] 3 NZLR 1 at [104].

26 At [123].

27 At [123].

${ }^{28}$ Claudia Geiringer "Shaping the interpretation of Statutes: where are we now in the s 6 debate?" in NZLS Using the Bill of Rights in Civil and Criminal Litigation (Continuing Legal Education NZLS, Wellington, 2008) at 4. 
Butler and Shaerf emphasise that the limits placed rights may be considered "fundamental" also. ${ }^{29}$ This observation is particularly apposite with regard to religious vilification laws. Religious freedom is another fundamental right guaranteed by the Bill of Rights Act. Section 13 protects the "right to freedom of thought, conscience, religion and belief, including the right to adopt or hold opinions without interference." While this doesn't elevate religious belief any higher than the freedom to hold other opinions, section 15 expressly protects the right of each person to "manifest [their] religion or belief in worship, observance, practice or teaching, either individually or in community with others, and either in public or in private." Section 20 further cements the rights of "ethnic, religious or linguistic minorities, in community with other members of that minority, to enjoy the culture to profess and practice the religion, or to use the language, of that minority." The Bill of Rights Act also protects the right to freedom of discrimination on the grounds of religion under s 19.

Therefore, should be borne in mind that freedom of religion is widely accepted as a fundamental human right also, both in domestic and international law. New Zealand must maintain a climate where a freedom to manifest one's religion can be enjoyed - the existence of religious vilification may limit the ability to enjoy this fundamental right. On the other hand, religious vilification laws may have unintended consequences in limiting the ability to manifest one's religion. For instance, legitimate evangelical activities posit one's own religion as preferable to another's. It is conceivable that this may move into the realm of vilifying others on the grounds of their religion, especially considering that the civil offence requires an objective assessment - no intention to incite hatred is required. The effects of a law on this important freedom must also be taken into account.

\section{$V$ The harm of vilification}

These laws aim to prevent the incitement of hatred or hostility in others. From a legal viewpoint, this is a curious phenomenon. There is no tangible harm to the bodily integrity of another, nor is any recognised psychiatric injury incurred. It is an inchoate offence: the elements of the offence are fulfilled if the behaviour is merely likely to incite hatred in others. Yet, if the offender succeeds in inciting hatred, the resulting feeling of hatred is

${ }^{29}$ Dr Andrew Butler and James Shaerf "Limiting Fundamental Rights: how on earth is s 5 supposed to work in practice?" in NZLS Using the Bill of Rights in Civil and Criminal Litigation (Continuing Legal Education NZLS, Wellington, 2008) at 25. 
not a crime. ${ }^{30}$ It is perfectly legitimate to hate another on any grounds, but it becomes an offence to share this hatred in public forums. However, advocates for vilification laws both on racial and religious grounds - point to the real harm that hatred causes to the victim.

This harm is primarily psychological, or the harm done to the target's status within society. ${ }^{31}$ Aleardo Zanghellini highlights the three possible effects of hate speech on the "feelings, beliefs or actions of an audience" as: ${ }^{32}$

1. the offence/distress produced by the speech act in the victimised hearer of the speech act;

2. the changes in the feelings, beliefs and attitudes of the victimised hearer of the speech act, whereby they remain silent in the face of vilification (which adversely impacts on the market of ideas), and generally refrain from sharing in the privileges of democratic citizenship on a par with others; and

3. the changes in the feelings, beliefs and attitudes of the non-victimised hearers of the speech act, whereby they end up treating members of the group targeted in the hateful utterance less favourably, and in extreme cases even perpetuating violence against them.

Although it is the most direct and therefore the most easily categorised as harm, legislating to prevent offence or distress felt by victims is problematic. Offence can be caused in everyday life entirely innocently. It cannot provide a meaningful touchstone for religious vilification. Each individual has a different level of sensitivity to offence. What level of offence must result before an expression becomes actionable?

New Zealand does have legislation to regulate "offensive or disorderly" words or behaviour in a public place. However, this has the central purpose of maintaining the public peace. In $R v$ Morse, Blanchard J described offensive behaviour as: ${ }^{33}$

\footnotetext{
${ }^{30}$ Ivan Hare "Crosses, Crescents and Sacred Cows: Criminalising Incitement to Religious Hatred" [2006] PL 521 at 533. See also David Nash and Chara Baklis "Incitement to Religious Hatred and the 'Symbolic': How Will the Racial and Religious Hatred Act 2006 Work?” (2007) 28 Liverpool Law Review 349 at 367.

${ }^{31}$ Simon Thompson "Freedom of expression and hatred of religion" (2012) 12 Ethnicities 215 at 226.

32 Aleardo Zanghellini "Jurisprudential Foundations for Anti-Vilification Laws: The Relevance of Speech Act and Foucauldian Theory" (2003) 27 Melb U L Rev 458 at 467, 480.

${ }^{33} R v$ Morse [2011] NZSC 45, (2011) 25 CRNZ 174 at [67].
} 
behaviour capable of wounding feelings or arousing real anger, resentment, disgust or outrage in the mind of a reasonable person of the kind actually subjected to it in the circumstances in which it occurs, so that there is directly or indirectly ... a disturbance of public order.

This is not analogous to legislating to prevent offence to victims. The disturbance to the public order is the harm that is being addressed, not the offence felt by the target. While this is also an impingement on the freedom of expression, the state's mandate to intervene to uphold peace and prevent violence is arguably a lot stronger than its mandate to interfere with individual autonomy to protect another's feelings.

It is arguable whether the second and third categories of harm - namely, direct harm to the victims, and indirect harm through changing society's view of the victims - are sufficiently serious to warrant the incursion on freedom of expression. The approaches of theorists such as Mari Matsuda, Kathleen Mahoney and Richard Delgado flesh out this harm. Concepts of human dignity and equality lie at the heart of their arguments.

\section{A The power of language}

The linguistic relativity hypothesis supports the suggestion that language can cause harm. Put simply, this is the proposal that "language influences and shapes our cognitive operations to a considerable degree". ${ }^{34}$ In a study suggested to evidence this hypothesis, two groups were given the same picture of two circles connected by a straight line. One group's picture was labelled "bar-bells", the other group's "eye-glasses". When asked to draw the picture from memory, many of those who saw the picture as "eye-glasses" changed the image, and drew the straight line as curved. ${ }^{35}$ Giving this example, Fergenson argues that ${ }^{36}$

[s]ince words clearly caused people to remember a picture in a distorted way, couldn't labelling do the same to their perceptions of a group of other people? ... [W] hat might occur if a people, such as the Jews, are continually described in vicious terms as a problem and given labels such as "vermin" or "parasites" (terms common in Nazi propaganda).

\footnotetext{
${ }^{34}$ Klaus Fiedler "Language: A Toolbox for Sharing and Influencing Social Reality" (2008) 3 Perspectives on Psychological Science 38 at 39.

${ }^{35}$ Laraine R Fergenson "Group Defamation: From Language to Thought to Action" in Monroe H. Freedman and Eric M. Freedman (eds) Group Defamation and Freedom of Speech: The Relationship between Language and Violence (Greenwood Press, Westport, 1995) 71 at 73.

36 At 73 .
} 
Language undeniably moves people to action. One need only look to the forces of media and marketing, political influence and negotiation. Hate speech can result in tangible detriment, for example in perpetuating discrimination in employment and social opportunities. The incitement of hatred exacerbates the target's difference within society.

New Zealand law does recognise the power of language in facilitating the commission of crimes. Under s 66(1) of the Crimes Act 1961, any person who "abets any person in the commission of the offence" or "incites, counsels, or procures any person to commit the offence" will be party to the offence. If the offence is not in fact committed, but is attempted, s 311 provides that any person who "incites, counsels, or attempts to procure any person to commit [that] offence... is liable to the same punishment as if he or she had attempted to commit the offence, unless in respect of any such case a punishment is otherwise expressly provided by this Act or another enactment." Therefore, if a person incites violence against another, and that violence is committed or attempted, this agitator can be found liable for the same offence as the principle. However, the incitement of hatred falling short of this can also cause significant harm.

\section{B Critical race theory and outsider jurisprudence}

In the United States, the freedom of expression guaranteed by the First Amendment has been afforded near-sacred status. Writing against this absolutist approach, Mari Matsuda has become a key voice in advocating for limitations on racial hate speech. Freedom of expression is usually justified in abstract, theoretical terms. Matsuda seeks to humanise the issue, acknowledging the need for history, individual experience, and context in crafting these laws. ${ }^{37}$ She suggests that "outsider jurisprudence - jurisprudence derived from considering stories from the bottom" - justifies limiting freedom of expression to prevent the perpetuation of racism. ${ }^{38}$ Her methodology is realist, acknowledging the political foundations of law, and rejecting the "presentist, androcentric, Eurocentric, and false-universalist descriptions of social phenomena." 39 The effects of majority power and domination over racial minorities underscore her work. Recognising the power of law "as a tool for social change", ${ }^{40}$ Matsuda forcefully argues for the need for laws to condemn

37 "The James McCormick Mitchell Lecture: Language as Violence v. Freedom of Expression: Canadian and American Perspectives on Group Defamation" (1988/89) 37 Buff L Rev 337 at 359.

${ }^{38}$ Mari J. Matsuda "Public Response to Racist Speech: Considering the Victim's Story" (1988-1989) 87 Mich L Rev 2320 at 2322.

39 At 2324.

40 At 2324. 
racist expression. Looking to the effects on victims, she presents a number of harms caused by hate speech.

Extreme hate speech may incite others to violence, but may also cause tangible physiological responses in its victims "ranging from fear in the gut, rapid pulse rate and difficulty in breathing, nightmares, post-traumatic stress disorder, hypertension, psychosis, and suicide" 41 It may cause its victims to adjust their behaviour in order to avoid receiving this vitriol, impeding their personal freedom. They may be encouraged to reject their identity as member of the targeted group. ${ }^{42}$ Matsuda writes of the profound effect that hate speech has on victims' self-esteem and sense of personal security: ${ }^{43}$

To be hated, despised, and alone is the ultimate fear of all human beings. However irrational racist speech may be, it hits right at the emotional place where we feel the most pain. The aloneness comes not only from the hate message itself, but also from the government response of tolerance.

This touches on the importance of religious vilification laws in ameliorating harm. The existence of institutional condemnation for this behaviour serves to offer support to victims of derogatory speech.

Furthermore, the existence of hate speech is divisive, and impacts upon the equality of citizens within society. Matsuda suggests that derogation ${ }^{44}$ plants [these messages] in our minds as an idea that may hold some truth. The idea is improbable and abhorrent, but because it is presented repeatedly, it is there before us. "Those people" are lazy, dirty, sexualised, money grubbing, dishonest, inscrutable, we are told. We reject the idea, but the next time we sit next to one of "those people", the dirt message, the sex message, is triggered.

This impedes inter-group social interaction - those targeted may be suspicious of the dominant group, and those "well-meaning dominant-group members [are forced] to use kid-glove care in dealing with outsiders". 45

Victims' civil and political rights are also marginalised by hate speech. If their voices are given less weight due to prevailing stereotypes, these people cannot enjoy a meaningful
41 At 2336.
${ }^{42}$ At 2337.
${ }^{43}$ At 2338.
${ }^{44}$ At $2339-2340$.
${ }^{45}$ At 2339. 
freedom of expression. ${ }^{46}$ They are unable to respond to the discourses that subordinate them. As Matsuda concludes, "[t]olerance of hate speech is not tolerance borne by the community at large. Rather it is a psychic tax imposed on those least able to pay." 47

In Matsuda's "outsider jurisprudence" approach, the harm of hate speech is assessed with reference to the individual, but it is an institution-level issue. She argues that episodes of racism cannot be dismissed as "isolated pranks", allowing the state to deny any responsibility. ${ }^{48}$ Kathleen Mahoney makes a similar point, characterising the incitement of hatred as a "social conflict between groups". Therefore, it is the government's role to delineate right from wrong, "marking where one set of claims legitimately begins and the other fades away". ${ }^{49}$ Indeed, characterising the incitement of vilification as a group issue adds weight to the argument for intervention. It takes on broader social significance beyond merely punishing individual anti-social behaviour. As Kevin Boyle has noted, human rights should not only be seen in terms of the individual. There is a communal interest in equality, also. ${ }^{50}$

\section{The harm of religious vilification}

Matsuda's outsider jurisprudence approach provides a helpful framework for assessing the harm of religious vilification, through focusing on the effects of religious hatred. However, her arguments concern racist vilification laws, a category she believes is best treated as sui generis. Racism is engrained, and steeped in a history of oppression. For this reason, vilification aimed at the majority race should not invoke legal sanction. ${ }^{51}$

An environment of severe religious oppression has never existed New Zealand, but there are certainly instances of negative stereotypes and religious discrimination. Albeit to a lesser extent than engrained historical racism, one could argue that these stereotypes and discrimination provide a similar context of intolerance that may be triggered with each

\footnotetext{
46 "The James McCormick Mitchell Lecture: Language as Violence v. Freedom of Expression: Canadian and American Perspectives on Group Defamation", above n 37, at 360.

${ }^{47}$ Matsuda, above n 38, at 2323.

48 At 2327.

49 Kathleen Mahoney "Hate Speech: Affirmation or Contradiction of Freedom of Expression" (1996) 3 U Ill L Rev 789 at 797.

${ }^{50}$ Kevin Boyle "Overview of a Dilemma" in Sandra Coliver (ed) Striking a Balance: Hate Speech, Freedom of Expression and Non-discrimination (Human Rights Centre, University of Essex, Colchester, 1992) at 7.

${ }^{51}$ Matsuda, above n 38, at 2357.
} 
expression of hostility. In contrast to an insult that may merely offend on a cosmetic level, expressions that draw upon engrained oppression or marginalisation as a springboard incur a greater level of harm, both to the individual and to society in perpetuating this idea.

Religious hate speech presumably incurs a similar harm to that of racial hate speech. For many, religious belief is a central feature of one's identity. It may be visible to others through clothing just as race is inscribed on one's skin. It may inform one's entire worldview and lifestyle. Those subjected to hostility or hatred on this ground would feel equally as marginalised from society as if the vilification was based on another ground. It is often suggested that the harm is lesser for religious vilification because, unlike race, religious belief is not immutable. ${ }^{52}$ Even when born into a religion, there is always an element of choice involved. Furthermore, there is a continuum of religious adherence that does not exist with respect to race. Adherents may adopt some elements of a religion but not others.

However, these distinctions do not succeed in denying the harm of religious vilification. Prosser's anti-Muslim statements will perpetuate the stereotype that Muslims are more likely to be terrorists and should therefore be viewed with suspicion. As Matsuda suggests, this stereotype may be triggered involuntarily. Whether these people have chosen to adopt Islam or not, linking their rights with the rights of terrorists will undoubtedly harm their standing within society. The question is whether the freedom to incite religious hostility is to be valued more than the social benefit in preventing the harms caused.

Matsuda's outsider jurisprudence helps substantiate the claim that religious vilification causes real harm. However, assessing the harm caused by racist hate speech in the United States has little relevance to an assessment of religious vilification in New Zealand. Further research needs to be done on the existence of religious hatred, and the impact upon its targets within the New Zealand context. That said, where it does exist it cannot be dismissed as mere words or fringe opinions, but as a harmful catalyst for intolerance and inequality within society.

52 See Eric Barendt Freedom of Speech (2ed, Oxford University Press, Oxford, 2005) at 190. 


\section{The freedom of expression}

The harm that is addressed by religious vilification laws must be balanced against the incursion on the freedom of expression. This must be gauged in light of the fundamental significance of the right. The philosophical, principled underpinnings of the freedom of expression provide a useful starting point for legislators. Moreover, as the limits on the freedom must be phrased in vague language (no bright line could possibly found for "inciting hatred"), these principles also often guide the court's application of legislation. ${ }^{53}$

Three core arguments have commonly been advanced to justify a broad freedom of expression. This part will explore the impact of religious vilification laws on these underlying rationales.

\section{A Freedom of expression is necessary for democracy}

The importance of free speech to a functioning liberal democracy is one of the strongest and most commonly called upon rationales for the freedom of expression. ${ }^{54}$ The idea originated with the American theorist, Alexander Meiklejohn, who argued that selfgovernment requires free speech so that the populace may be educated in political matters. ${ }^{55}$ The ability to freely debate matters of public and political interest has been considered so central to a functioning democracy that the High Court of Australia has implied a right of freedom of political speech into the Constitution. As Brennan J stated: ${ }^{56}$

[I]t would be a parody of democracy to confer on the people a power to choose their

Parliament but to deny the freedom of public discussion from which he people derive their political judgments.

James Weinstein suggests that there are two components to the concept of democracy. Firstly, democracy means "popular sovereignty". ${ }^{57}$ In order to exercise this, it is necessary that the people have the freedom to discuss matters of public concern. If the state limits this freedom, ultimate sovereignty does not reside with the people, but must

\footnotetext{
${ }^{53}$ Barendt, above $\mathrm{n}$ 52, at 3.

${ }^{54}$ Barendt, above n 52, at 18.

${ }^{55}$ See Alexander Meiklejohn "The First Amendment is an Absolute" (1961) Supreme Court Review 245.

${ }^{56}$ Nationwide News Pty Ltd $v$ Wills (1992) 177 CLR 1 at 47.

${ }^{57}$ James Weinstein "Extreme Speech, Public Order, and Democracy: Lessons from The Masses" in Ivan Hare and James Weinstein (eds) Extreme Speech and Democracy (Oxford University Press, Oxford, 2009) 23 at 25.
} 
reside with the state. ${ }^{58}$ Secondly, democracy requires the equal participation of all in the political process. This goes beyond equal voting rights; each citizen has the right to "participate in the discussion by which public opinion is formed". 59

While Australian jurisprudence confines this principle to speech concerning politics, the argument from democracy is best cast more broadly. Quoting Eric Barendt, Weinstein suggests that the speech feeding into this public opinion is not merely "political speech in the narrow sense", but includes "speech concerning the organisation and culture of society" more generally. ${ }^{60}$ This avoids the difficulties in distinguishing strictly political speech from the public concerns that feed into the administration of the country. Political decisions are intensely contextual and cannot be easily separated from cultural or social matters.

Given that democracy mandates democratically elected officials to make decisions on behalf of the citizenry, it may be argued that legislative limits are legitimate. ${ }^{61}$ However, any attempt by the government to limit people's ability to contribute to public discourse can be seen as undermining what Robert Post terms "democratic legitimacy". ${ }^{62}$ Selfgovernment, he says, requires that "people have a warranted conviction that they are engaged in the process of governing themselves. ${ }^{63}$ The freedom of expression is required so that every citizen can feel connected to the decisions made on their behalf. For this, every citizen must be treated equally. If the state privileges certain individuals or groups, for example through limiting one group's freedom to participate in public discourse, " $[\mathrm{t}]$ he state thereby loses its claim to democratic legitimacy with respect to those citizens. ${ }^{\circ 64}$ One could argue that this further degrades the democratic legitimacy of the system as a whole - the public opinion cannot be considered truly public when some voices are barred. "[C]ollective decision-making is merely oppressive unless there is

\footnotetext{
58 At 26.

59 At 27.

${ }^{60}$ At 29, citing Barendt, above n 52, at 189.

${ }^{61}$ Barendt, above n 52, at 19.

62 Robert Post "Democracy and Equality" (2006) 603(1) ANNALS of the Am. Acad, Pol. \& Soc. Sci. 24 at 24.

${ }^{63}$ At 26.

${ }^{64}$ At 29.
} 
some internal connection between the particular wills of individual citizens and the general will of the collectivity." 65

\section{Religious vilification laws and democracy}

Religious vilification laws remove certain forms of expression from the public sphere on the grounds that these expressions might incite hostility towards others on this prohibited ground. These laws therefore overtly control the formation of public opinion. The HRA offences are only invoked when the expressions are published, distributed, used in a public place or (for the civil but not the criminal offence) in a manner likely to become published. Private vitriol is acceptable. Therefore, in passing vilification laws, the state demarcates religious hostility as an illegitimate contribution to the public pool of thought. Under the argument from democracy, this detracts from the democratic legitimacy of the system.

Religion presents an interesting challenge within freedom of expression jurisprudence. On the one hand, religion is often a core feature of a person's identity, thus arguably deserving regulation in order to protect the dignity and self-esteem of its adherents, just as race is protected. On the other, it is a body of ideas informing the worldview of a group of people. Religious beliefs have public implications. Religious groups are often at the forefront of controversial social and political issues such as same-sex marriage, abortion and euthanasia. Moreover, even where religious groups are not overtly addressing political matters, religious values and ideas held by members of the public provide an undercurrent to public debate.

Proponents of these laws are careful to argue that their purpose is to prevent harm caused to the religious person and not to the ideas themselves. The freedom to cause extreme offence others has less social utility than the ability to debate ideas. However, it is questionable whether a valid distinction can be drawn between the harm caused by the vilification of the person and the harm caused by the vilification of a person's fundamentally held beliefs. This is a salient point, which has arisen throughout the religious vilification law debate. As Harrison has written, "there is no real difference

${ }^{65}$ Robert Post "Religion and Freedom of Speech: Portraits of Muhammad" in András Sája (ed) Censorial Sensitivities: free speech and religion in a fundamentalist world (Eleven International Publishers, Portland, 2007) 329 at 334. 
between saying "Christianity is evil" as opposed to "all Christians are evil" - both have the potential to incite religious hatred." 66

Arguably, the effect of religious vilification laws is to afford religious groups preferential status within public debate. Other ideas may be derogated freely and with any level of offensive vigour. However, expressions that can be characterised as inciting hostility against religious people may incur legal sanction. This argument would carry more force if religious vilification laws were not cast so narrowly. Only the most egregious forms of expression will meet the threshold: those that attack the person and not the idea. Vilification laws catch expressions that aim to foster a visceral, emotive response in others. Robust criticism based in reason, rather than in emotionally loaded epithets, will not be caught. These laws do not put religious ideas beyond reproach within the democratic system, but restrict the way that criticism is presented. The o

Furthermore, vilification laws may be defended in that they foster the environment of equality and autonomy emphasised by Post as a central tenet of democracy. Discrimination and vilification prevents target groups from participating fully in the democratic process, as their credibility is lessened. ${ }^{67}$ As the targets' voices are not represented within the public opinion, they are effectively estranged from the democratic process.

This discussion highlights the significance of fostering an environment where no individual or group of individuals are barred from participating in the democracy. It is debatable whether state-imposed restrictions on extreme speech will be more successful in creating this equality than other mechanisms such as community education.

\section{B Freedom of expression is necessary to the discovery of truth}

A second foundational justification for free expression is that it is required in the pursuit of truth. John Stuart Mill originally asserted that even false speech ought to be protected as it leads to greater insight. The existence of the false statement offers the opportunity

${ }^{66}$ Joel Harrison "Truth, Civility, and Religious Battlegrounds: The Contest Between Religious Vilification Laws and Freedom of Expression" (2006) 12 Auckland U. L. Rev. 71 at 78 .

${ }^{67}$ Mahoney, above n 49, at 792. 
for it to be debunked and the truth affirmed. ${ }^{68}$ Mill recognised that truth was dynamic: "however true [an expression] may be, if it is not fully, frequently, and fearlessly discussed, it will be held as a dead dogma, not a living truth"69

A variation of Mill's argument from truth is found in the "marketplace of ideas" metaphor. As stated by Holmes $\mathrm{J}$ in his dissenting judgment in Abrams $v$ US: ${ }^{70}$

But when men have realized that time has upset many fighting faiths, they may come to believe even more than they believe the very foundation of their own conduct that the ultimate good desired is better reached by free trade in ideas - that the best test of truth is the power of thought to get itself accepted in the competition of the market, and that truth is the only ground upon which their wishes safely can be carried out.

Government regulation of the marketplace distorts the free-market exchange of ideas. ${ }^{71}$

These arguments best apply to situations where truth cannot be established with certainty. ${ }^{72}$ The "true" option may be read to mean the "best possible option", when all ideas and issues are pooled and compared. For instance, Mahlmann asserts that the truth argument extends to "experiments of living", which provides useful information to the community about the so-called "good life". 73

As Andrew Geddis highlights, freedom of expression discussions often centre on an archetypal figure:

the individual who, spurred by the strength of her convictions, is prepared to give public expression to dissenting or aberrant views even when those witnessing the display react with hostility or contempt.

Concepts of right versus wrong and visions of the noble underdog are rarely this clear in practice.

Whether an objective "truth" can ever by identified is doubted in modern epistemology. ${ }^{74}$ What is "true" will always be relative, and will be shaped by the dominant discourses

${ }^{68}$ Matthias Mahlmann "Free Speech and the Rights of Religion" in András Sája (ed) Censorial Sensitivities: free speech and religion in a fundamentalist world (Eleven International Publishers, Portland, 2007) 41 at 54.

69 John Stuart Mill On Liberty (1859) The University of Adelaide Library <https://ebooks.adelaide.edu.au/m/mill/john_stuart/m645o/>.

${ }^{70}$ Abrams v US (1919) 250 US 616 at 630-1.

${ }^{71}$ Barendt, above n 52, at 11.

${ }^{72}$ Barendt, above n 52, at 10.

${ }^{73}$ Mahlmann, above n 68, at at 56.

${ }^{74}$ Mahlmann, above n 68, at 54. 
within society. Therefore, the dissenting individual is the "place holder", ${ }^{75}$ showing the extent to which individual autonomy exists within the civic structure of society, and contesting dominant understandings of the "truth". Under the argument from truth, the existence of opposition will allow the best idea to come to the fore. In our democratic system, this "best idea" or "truth" will generally be the idea most acceptable to the majority.

\section{Religious vilification laws and the search for truth}

Under this theory, religious vilification laws give rise to the concern that certain values and ideas will only be able to be debated to a limited extent. Adopting the current HRA language, under a parallel religious vilification law, those disagreeing with elements of a religious belief will not be able to present criticism in a manner that is "threatening, abusive or insulting" if it is likely to "excite hostility or contempt" on the ground of religion. Two questions require discussion:

(a) What truth is being sought?

The relationship between truth and religious belief is particularly inflammable, given that a number of religions take claim to the sole, divine "truth". These are presented as concrete and certain. As such, they are prone to attack. Evidence regarding the truth of one religious belief as opposed to another religious (or non-religious) belief cannot be produced. A freedom of expression cannot allow the religious "truth" to come to the fore. Islam cannot be discussed as more or less "true" than Christianity.

The "truth" at issue within this theory is best phrased in terms of the most desirable values and beliefs within society. Religious beliefs in are relevant in terms of human rights, for example. As stated above, because religious belief informs these public issues, the argument from truth complements the argument from democracy. Conceptually, the truth of the day should lie closely to the public opinion that informs democratic decisionmaking.

75 Andrew Geddis "Free Speech Martyrs or Unreasonable Threats to Social Peace? "Insulting" Expression and Section 5 of the Public Order Act 1986" [2004] PL 853 at 853. 
(b) Will this debate function properly with a religious vilification law in existence?

Religious values and beliefs can still be debated with religious vilification laws, so long as this debate is not framed in vitriolic terms likely to incite hostility in others. These laws sanitise public discourse, but do not prevent the expression of ideas themselves.

However, sanitising public discourse, even to a small extent, is problematic for a number of reasons. Firstly, it is possible that in requiring ideas to be expressed in more temperate language, the nuance and precise meaning will be lost. ${ }^{76}$ This was recognised by the United States Supreme Court in Cohen v California. In overturning Cohen's conviction for wearing a jacket bearing the words "Fuck the Draft", the court rejected "the facile assumption that one can forbid particular words without also running a substantial risk of suppressing ideas in the process". ${ }^{77}$

Secondly, the impact of the expression - its ability to compete with other ideas in the public sphere - may be lessened. A major flaw in the marketplace of ideas theory is that in reality, the marketplace is not open to all. ${ }^{78}$ Some ideas are given additional weight through media dissemination. Others belong to those with the power or finances to ensure that they are accepted. In this context, offence is a useful tool in demanding attention and giving more force to minority ideas within the marketplace. Allowing the legislature to limit the boundaries of public discourse limits minorities' ability to check majority power and undermines the principles of autonomy and democracy within the system. It swings the balance of power away from the people and toward the state.

Thirdly, vilification laws have the effect of privileging intellectual discussion, creating additional barriers to popular participation in the marketplace. They deter the participation of those with valid ideas but an inability (or lack of desire) to express them in more eloquent terms. Because well-expressed ideas are more likely to be accepted than those in rash, emotive language, it is important that institutional barriers are not added also. Democracy requires the participation of people from all backgrounds and education levels.

\footnotetext{
${ }^{76}$ Hare, above $\mathrm{n} 30$, at 527.

${ }^{77}$ Cohen v California (1971) 405 US 15 at 26.

${ }^{78}$ Barendt, above n 52, at 12.
} 
Fourthly, the distinction between the harm caused by venomous abuse as opposed to intellectual theorising may be overstated. As Harrison writes: ${ }^{79}$

what is more sinister, creating a theory of "raceology" that advocates a voluntary programme of sterilisation for those with "deficient" genes, thus remedying the "tragedy" of the American Negroes I.Q. deficiency, or the vitriolic statement of the bigot? Granted, the vitriolic statement has a greater immediate effect of terror, but the "academic" statement forms the structural basis that legitimises the latter.

The harm at issue here is not only the emotional harm to the victim, but the long-term detriment to equality within society. Suppressing overt, extreme hostility may be counterproductive. If these ideas are driven underground, they may manifest themselves in more dangerous forms. ${ }^{80}$ Inequality and "otherness" of target groups is driven by misunderstanding and instinctive discrimination - phenomena which are impossible to legislate for. Outrageous, bigoted claims offer the opportunity for public correction. It is easy to highlight the flaws in these claims. Assuming that a general culture of equality exists, upon seeing these messages, members of the public will be offended. In disputing the hateful claims, the public can re-affirm its commitment to equality. ${ }^{81}$

Furthermore, the target group themselves are drawn into public discourse. They are not necessarily always marginalised by the existence of this speech. For example, after the offensive Mohammed cartoons were published in Denmark in 2006, Muslim voices were heard throughout the world. As Ian Cram has argued, this episode revealed Muslims' "healthy commitment to the idea that the could shape the contours of public policy." 82 They were not marginalised by their feelings of offence.

Because there is no way of phrasing the laws to give a certain, bright line, the application of elastic terms will depend on judicial interpretation. In the context of s 6 of the Bill of Rights Act and New Zealand's judicial tradition of upholding the freedom of expression, these laws are likely to be applied narrowly. Furthermore, it could be argued that the impact on the marketplace of ideas is small, because the inciting matter must be published before an offence is committed. Language is not barred as such, but is rather

\footnotetext{
${ }^{79}$ Harrison, above n 66, at 87.

${ }^{80}$ Barendt, above n 52, at 9.

${ }^{81}$ Harrison, above n 66, at 82; citing Bollinger, The Tolerant Society: Freedom of Speech and Extremist Speech in America (1986) 126.

${ }^{82}$ Ian Cram "The Danish Cartoons, Offensive Expression, and Democratic Legitimacy" in Ivan Hare and James Weinstein Extreme Speech and Democracy (Oxford University Press, Oxford, 2009) 311 at 330.
} 
sanctioned as illegitimate after the fact. This is a minor point however, as potential hatemongers are bound to self-censor in order to avoid penalties. In the absence of clear guidance of the threshold for inciting hostility, the self-censorship will occur at a lower level of seriousness. Therefore, the impact of vilification laws on the ability to freely present ideas within the marketplace will go beyond the judiciary's actual interpretation of the legislation.

That said, on the whole, the impingement of religious vilification laws on the marketplace of ideas would be slight. It is only the most extreme language that it restricts, and these vitriolic statements can, and should, be reframed in more temperate language to enable a fruitful discussion of religious matters.

\section{Freedom of expression is necessary for human self-fulfilment}

Whereas the prior two arguments treat freedom of expression as a necessary ingredient for a functioning society, freedom of expression can also be framed as an "intrinsic, independent good" in itself; a human right accorded to individuals. ${ }^{83}$ Mahlmann describes the need to express oneself as a central component of human existence. The ability to construct and decipher symbols representing the world is necessary in order to overcome life's isolation and subjectivity. ${ }^{84}$ Along with the converse freedom to receive opinions, the freedom of expression also contributes to the development of one's personality and intellect. This will help foster a more educated, thoughtful populace and therefore benefit society. ${ }^{85}$

\section{Religious vilification laws and self-fulfilment}

Self-fulfilment alone provides a weak justification for the freedom of expression, considering the harm that can be occasioned by untrammelled speech. In his discussion of the freedom of expression rationales in Hosking $v$ Runting, Tipping $\mathrm{J}$ noted that this "liberal theory" is particularly broad and problematic: ${ }^{86}$

The liberty theory rests on the ultimate public good; but the full flowering of the theory undoubtedly has the capacity to harm the public good. When the expression in issue provides little public benefit, except in theory, but significant individual or public harm in concrete terms, the theory must give way.

\footnotetext{
${ }^{83}$ Barendt, above n 52, at 13.

${ }^{84}$ Mahlmann, above n 68, at 57.

${ }^{85}$ Mahlmann, above n 68, at 57.

${ }^{86}$ Hosking v Runting [2004] NZCA 34; [2005] 1 NZLR 1 at [234].
} 
Any personal growth obtained from hatemongering should be outweighed by the damage done to other individuals' self-fulfilment.

However, religion complicates the exercise of balancing the expression's harm against the speaker's self-fulfilment. The harm to the target group may be dealt in the course of the speaker manifesting his or her religion. Vilification laws do not only apply to members of the majority who are inciting hatred for marginalised minorities. There is a strong link between the freedom of religion and self-fulfilment. Religion provides meaning and identity for its adherents. The significance of this self-fulfilment ought also to be taken into account in assessing the harm caused to others.

Vilification laws are therefore problematic in interfering with the freedom of religion. There is a danger that these will impinge on the freedom for a person to manifest their religious belief. As is discussed in Part VII, recent Australian case law indicates that this remains a problem even where the legislation safeguards the incitement of hatred engaged in for a "genuine... religious purpose." ${ }^{87}$ Legitimate evangelical activities, for instance, may still fall within the law's scope.

\section{Analysis}

It is clear that a religious vilification law impacts upon the traditional justifications of an untrammelled freedom of expression. In pure liberal theory terms, state-dictated boundaries of speech undermine the notion of popular rule. However, this is easily rebutted: the state holds the popular mandate for governing society. The state's ability to exercise its power is a vital element of democracy - boundaries must be drawn somewhere. More significant is the concern that in protecting against religious vilification, religious ideas with political (or public) significance will be privileged within wider debate. This will impede the democratic process. However, the contrary argument may also be made that these laws foster a more inclusive democratic system through ensuring that no group is marginalised and excluded from civic participation.

The argument that free expression is necessary in order to discover the truth feeds into this democratic argument: ideas must be debated in order to come to the "best theory", or what we may understand to be the "truth". Sanitising discussion limits the expression of a particular, nuanced idea, and prevents extreme offence from being used as a tool to have

${ }^{87}$ Racial and Religious Hatred Act 2001 (Vic), s 11. 
one's point heard. It privileges intellectual discussion in a way that may not be commensurate with the differences in harm caused.

The self-fulfilment of the speaker is a more precarious justification for the freedom to express religious vilification. The self-fulfilment gained by causing harm to others must be seen as illegitimate. However, if the exercise of one's religion falls foul of religious vilification laws, the importance of religious self-fulfilment becomes more pertinent.

It is important to note that these theories have developed under a liberalist notion that there should be no intervention - or extremely minimal intervention - in an individual's liberty to express any opinion or idea whatsoever. This stance may be arguable under the First Amendment to the United States Constitution, which provides that "Congress shall make no law... abridging the freedom of speech". However, s 5 of the BORA expressly recognises the legitimacy of state-imposed limits on this freedom. The theories reflect the traditional United States' suspicion of government and desire to protect individual autonomy. Our culture tends to be more collectivist. Grant Huscroft suggests that this ethic explains why it took until 1991 before the Bill of Rights Act was passed, and why it was passed as ordinary legislation. ${ }^{88}$ Unlike in the United States, New Zealand's Bill of Rights is neither supreme nor entrenched law; Parliament could (in theory) alter legislation concerning fundamental human rights just as they could any other enactment. This is not to suggest that individual rights against the state are not significant in New Zealand, but that these must be seen in their wider context, particularly with respect to the harm that an absolutist approach may cause.

Discussing the issue in the abstract, it is difficult to balance the harm against the incursion on the freedom of expression theories. Much depends on one's view of the legitimacy of government intervention into personal autonomy. Barendt poses the apt question:

is there any reason to be particularly suspicious of government regulation of free speech, compared with censorship or interference by other bodies such as churches, commercial companies, or even media organisations?

The reality is complex. There are innumerable forces that act on the way that the public understanding is shaped, and many are very difficult to regulate. For instance, how does one regulate the media's tendency to stereotype certain groups? Who is to decide what is a legitimate and what is an illegitimate depiction? Arguably, discussions of principle alone bring us to an intellectual impasse. Stanley Fish's iconoclasm may resonate, in that

${ }^{88}$ Huscroft, above n 2, at 174. 
“abstract concepts like freedom, rights, and free speech don't have any 'natural' content but are filled with whatever content and direction one can manage to put into them". ${ }^{89}$ Therefore, the core rationales provide only one facet of the proportionality inquiry. The practical effects of these laws need to be investigated.

\section{The experience in Victoria, Australia}

In considering implementing a religious vilification law, New Zealand has the advantage of other jurisdictions' experiences. The Victorian Racial and Religious Tolerance Act 2001 provides a scheme of civil and criminal offences similar to New Zealand's Human Rights Act, that could model for an expanded New Zealand approach. However, it has had a controversial existence. The Islamic Council of Victoria $v$ Catch the Fire Ministries case exemplifies the issues with the Victorian law and provides a useful factual matrix for analysing the practical effects of religious vilification legislation. ${ }^{90}$

\section{A The Racial and Religious Tolerance Act 2001 (Vic)}

The Act creates identical civil and criminal offences for racial and religious vilification. At the heart of the Victorian Racial and Religious Tolerance Act 2001 lies the need to support equality in a culturally diverse environment. The Preamble to the Act acknowledges the significance of the freedom of expression, saying that it should only be limited "to the extent that it can be justified in an open and democratic society". The "right to participate equally in society" is identified as a legitimate justification.

\section{Civil offence}

Section 8 provides that:

(1) A person must not, on the ground of the religious belief or activity of another person or class of persons, engage in conduct that incites hatred against, serious contempt for, or revulsion or severe ridicule of, that other person or class of persons.

(2) For the purposes of subsection (1), conduct-

(a) may be constituted by a single occasion or by a number of occasions over a period of time; and

${ }^{89}$ Stanley Fish There's No Such Thing as Free Speech (Oxford University Press, Oxford, 1994) at 102.

${ }^{90}$ Islamic Council of Victoria Inc v Catch the Fire Ministries Inc [2004] VCAT 2510; Catch the Fire Ministries Inc v Islamic Council of Victoria Inc [2006] VSCA 284. 
(b) may occur in or outside Victoria.

Identical language is found in $\mathrm{s} 7$ in prohibiting the same conduct on the grounds of race. Race is defined broadly to include colour, descent or ancestry, nationality or national origin, ethnicity or ethnic origin.

The focus of the offence is clearly on the effect that this incitement will have on others. No intention to incite hatred ${ }^{91}$ is required to commit the offence - the inciter's motivation is irrelevant. ${ }^{92}$ It is not necessary for the target's race or religion to be the only or the dominant ground for the conduct, so long as it is a "substantial ground". ${ }^{93}$ Similarly, an offence will still be committed under ss 7 or 8 even if the inciter incorrectly assumed that the target was of a certain race or held a certain religious belief. ${ }^{94}$

This focus is also reflected in the defences provided within the Act. Private conduct will not fall under the religious vilification provisions. No offence will be committed if the circumstances reasonably indicate that a) the parties did not desire anybody else to see or hear their conduct; and b) the parties would not reasonable expect that anybody else would see or hear their conduct. ${ }^{95}$

Certain socially beneficial forms of expression are also protected. Section 11 provides that:

(1) A person does not contravene section 7 or 8 if the person establishes that the person's conduct was engaged in reasonably and in good faith -

(a) in the performance, exhibition or distribution of an artistic work; or

(b) in the course of any statement, publication, discussion or debate made or held, or any other conduct engaged in, for -

(i) any genuine academic, artistic, religious or scientific purpose; or

(ii) any purpose that is in the public interest; or

(c) in making or publishing a fair and accurate report of any event or matter of public interest.

(2) For the purpose of subsection (1)(b)(i), a religious purpose includes, but is not limited to, conveying or teaching a religion or proselytising.

\footnotetext{
${ }^{91}$ Or the other prohibited emotions.

92 Section 9(1).

${ }^{93}$ Section 9(2).

${ }^{94}$ Section 10.

${ }^{95}$ Section 12.
} 
Therefore, the motive of the conduct is only relevant as a defence. ${ }^{96}$

If a breach occurs, the aggrieved person (or an authorised representative) may take the issue to the Victorian Equal Opportunity and Human Rights Commission (VEOHRC). The Commission facilitates a voluntary, flexible dispute resolution process, which may then result in a binding settlement. ${ }^{97}$ Whether or not the dispute has been brought before the VEOHRC, the dispute may be referred to the Victorian Civil and Administrative Tribunal (VCAT).$^{98}$ The VCAT has the power to hear evidence and decide whether the Act has been contravened. Upon finding a contravention, it may then make a range of orders. $^{99}$

\section{Criminal offence}

Criminal liability attaches to instances of serious vilification. Section 25 provides that:

(1) A person... must not, on the ground of the religious belief or activity of another person or class of persons, intentionally engage in conduct that the offender knows is likely -

(a) to incite hatred against that other person or class of persons; and

(b) to threaten, or incite others to threaten, physical harm towards that other person or class of persons or the property of that other person or class of persons.

(2) A person must not, on the ground of the religious belief or activity of another person or class of persons, knowingly engage in conduct with the intention of inciting serious contempt for, or revulsion or severe ridicule of, that other person or class of persons.

If found guilty, the offender may face 6 months' imprisonment or a fine of 60 penalty units. That the offender may have based his conduct on an incorrect assumption as to the target's race or religious belief is irrelevant. ${ }^{100}$ Requiring the written consent of the Director of Public Prosecutions, this law is not commonly drawn upon.

${ }^{96}$ Patrick Parkinson "Enforcing Tolerance: Religious Vilification Laws in Australia" (Paper presented at the Eleventh Annual International Law and Religion Symposium, "Religion in the Public Sphere: Challenges and Opportunities", Provo, Utah, 3-6 October 2004) at 5.

${ }^{97}$ See Racial and Religious Tolerance Act 2001 (Vic), Part 3, Division 1; and Equal Opportunities Act 2010 (Vic), Part 8, Division 1.

${ }^{98}$ Racial and Religious Tolerance Act 2001, s 23.

${ }^{99}$ Section 23C.

${ }^{100}$ Section 26. 


\section{B Islamic Council of Victoria $v$ Catch the Fire Ministries}

The Catch the Fire Ministries case highlights the interpretive and practical difficulties with the Victorian vilification legislation. The Islamic Council of Victoria (ICV) alleged that Pastor Daniel Scot, Pastor Danny Nalliah, and their evangelical organisation Catch the Fire Ministries (CTFM) breached s 8 of the Racial and Religious Tolerance Act. The ICV complained to the VCAT after three of its members attended a CTFM seminar held by Scot in March 2002. Their complaint concerned the seminar, and also an article and a newsletter posted on the CTFM website. ${ }^{101}$

The article, "An Insight into Islam by Richard", was written by a third party and featured on the website. Dated two weeks after the 11 September terrorist attacks in 2001, it suggested that terrorism is a fundamental element of the inherently violent Islamic religion. ${ }^{102}$ The newsletter was written by Pastor Nalliah and entitled "2020 - Will Australia be a Christian Country?" In it, Nalliah wrote of the influx of Muslims entering Australia from countries where Christians are being raped, tortured and killed: "what stops the Muslims from doing the same in Australia?" Nalliah also states that Muslims have infiltrated Parliament, and intend to "make everyone in Australia worship Allah [t]hrough peace or through violence." 103

The major complaint centred on Scot's seminar, entitled "Insight into Islam". It was advertised on the CTFM website and on posters. Approximately 200-250 were in attendance. At the seminar, Scot discussed "witnessing" to Muslims, discussing how to socialise with them and convert them to Christianity. ${ }^{104}$ The ICV alleged that Scot's interpretation of Islam, based on his literal reading of the Qur'an, incited hatred on religious grounds. The VCAT found that during the seminar, Scot made 19 offensive statements, including that: ${ }^{105}$

(1) the Qur'an promotes violence, killing and looting;

(2) Muslim scholars misrepresent what the Qur'an says by varying the emphasis depending on the audience

(3) the Qur'an teaches that women are of little value

${ }^{101}$ Islamic Council of Victoria Inc v Catch the Fire Ministries Inc [2004] VCAT 2510.

102 At [394].

103 At [391]-[392].

104 At [81].

105 At [80], [383]. 
(4) Muslims are demons

(5) Muslims have a plan to overrun western democracy [including Australia] by the use of violence and terror, and to replace those democracies with oppressive regimes;

(6) Muslim people have to fight Christians and Jews [and] humiliate them... until they accept true religion.

\section{$1 \quad V C A T$}

Regarding the seminar, the VCAT found that the test for section 8 was met: ${ }^{106}$

the ordinary reasonable reader who is not malevolently inclined or free from susceptibility to prejudice would be inclined to hatred, ridicule, contempt or revulsion by reason of the presentation of the seminar.

The seminar "was not a balanced discussion" but rather: 107

Scot, throughout the seminar, made fun of Muslim beliefs and conduct. It was done, not in the context of a serious discussion of Muslims' religious beliefs; it was presented in a way which is essentially hostile, demeaning and derogatory of all Muslim people, their god, Allah, the prophet Mohammed and in general Muslim religious beliefs and practices.

According to the VCAT, no defence was available. The pastors had the onus under s 11 to show that the seminar was engaged in "reasonably and in good faith in the course of... discussion... for any religious purpose or any purpose that is in the public interest."108 "Good faith" required subjective honesty, and when viewed objectively the person must have also "taken a conscientious approach to minimising the exercising of that freedom in a way that is designed to minimise the offence or insult, humiliation or intimidation suffered by people affected by it."109 "Reasonableness" required a rational, proportionate relationship between the conduct and the purpose. ${ }^{110}$ The VCAT doubted Scot's subjective good faith, and further found that the seminar was "excessive", and "a onesided delivery of a view of the Qur'an and Muslim's beliefs, which were not representative." 111 Scot's interpretation of the Qur'an did not represent "mainstream

\footnotetext{
106 At [384].

107 At [383]-[384].

108 At [388].

${ }^{109}$ Bropho v Human Rights and Equal Opportunity Commission [2004] FCAFC 16 at [104].

${ }^{110}$ Bropho, above n 109, at [75].

${ }^{111}$ Islamic Council of Victoria Inc v Catch the Fire Ministries Inc, above n 101, at [389].
} 
Muslim beliefs", but rather attributed extreme Wahabbi fundamentalist beliefs to all Australian Muslims. ${ }^{112}$

The newsletter and article also breached s 8. The VCAT found that the newsletter was likely to incite hatred towards Muslims, as it sought to foster in the readers a fear of harm at the hands of Muslims. ${ }^{113}$ Although the September 2001 article was not written by either of the pastors, the VCAT found that placing it on the internet was an act inciting hatred of Muslims.

The VCAT ordered that the pastors place apologies on the CTFM website, and in two major Victorian newspapers on two different nights. It was estimated that these would cost $\$ 67,690 .{ }^{114}$ They were also required to undertake that they would not make any similar written or oral statements in any state in Australia. ${ }^{115}$

\section{Victorian Court of Appeal}

In highlighting the errors of law in the VCAT decision, the Court of Appeal clarified the proper approach to the Victorian religious vilification laws.

According to the VCAT, Scot's statements breached s 8 because they were made on the grounds of Muslim beliefs, and an "ordinary reasonable person who was not malevolently inclined or free from susceptibility to prejudice would be inclined by Pastor Scot's statements to hate Muslims." 116 However, the Court of Appeal found that this test led the judge into error in not centring on the effect on the audience. According to Nettle JA, rather than the "ordinary reader", the actual audience - whether it be as broad as the readership of a website, or as narrow as a seminar audience - must be taken into account. The question is whether the "natural and ordinary effect of the conduct is to incite hatred or other relevant emotion in the circumstances of the case" on a "reasonable member of the class of persons to whom the conduct is directed." ${ }^{117}$ While Ashley and Neave JJA preferred the "ordinary member" to Nettle JA's "reasonable member of the class", they

\footnotetext{
112 At [387].

113 At [392].

${ }^{114}$ Harrison, above n 66, at 88.

115 Islamic Council of Victoria $v$ Catch the Fire Ministries Inc [2005] VCAT 1159.

${ }^{116}$ Catch the Fire Ministries Inc v Islamic Council of Victoria Inc [2006] VSCA 284 at [30].

117 At [18]-[19].
} 
otherwise agreed with Nettle JA's test. ${ }^{118}$ Therefore, it was inappropriate to place any weight on the offence felt by the Muslim witnesses. ${ }^{119}$

The Court also clarified that within s 8, "on the grounds of religious belief" does not mean that the conduct must be motivated by the target's religious belief, but that the audience must be incited to hatred due to the religious belief. As per s 9, the inciter's motivation is irrelevant. ${ }^{120}$ The VCAT was incorrect in construing this in terms of the inciter's motivation. The VCAT was correct, however, in finding that the audience does not need to be actually incited to hatred; $s$ will be breached "if the words or conduct has the tendency to incite that response." 121

The VCAT's incorrect construction of s 8 led to a number of errors of law. Firstly, the discussion of whether the representation of Islam was "balanced" or "accurate" was irrelevant. As Nettle JA noted: ${ }^{122}$

Statements about the religious beliefs of a group of persons could be completely false and utterly unbalanced and yet do nothing to incite hatred of those who adhere to those beliefs. At the same time, statements about the religious beliefs of a group of persons could be wholly true and completely balanced and yet be almost certain to incite hatred of the group because of those beliefs.

Furthermore, this required the secular VCAT to address the "theological propriety" of the statements. $^{123}$

Scot's presentation of a one-sided, fundamentalist version of Islam based on a literal construction of the Qur'an was sufficient for the VCAT find that he had breached s 8 . However, for Nettle JA, the VCAT failed to distinguish between hatred of religious beliefs and hatred of the religious person. This was an important error of law: ${ }^{124}$

No doubt the purpose of the Act is to promote religious tolerance. But the Act cannot and does not purport to mandate religious tolerance... s 8 goes no further in restricting freedom to criticise the religious beliefs of others than to prohibit criticism so extreme as to incite hatred or other relevant emotion of or towards those others.

118 At [132] per Ashley JA; at [160] per Neave JA.

119 At [64]-[67] per Nettle JA; at [187] per Neave JA.

${ }^{120}$ At [138]-[152] per Neave JA.

121 At [153]-[154] per Neave JA.

122 At [36].

123 At [36].

${ }^{124}$ At [34]. 
Yet, Neave JA makes less of this distinction. In her opinion, it was open to the Tribunal to find "statements attacking religious belief as capable of inciting reactions of severe contempt, revulsion or serious ridicule of Muslim persons". This is a question of fact, to be considered in light of the social and historical context. ${ }^{125}$

The Court held that Judge Higgins failed to consider the ameliorative effect of Scot's appeals to love Muslims. Listening to recordings of the seminar, Nettle JA found that although Scot's style was "given to ridicule at places", and resulted in audience laughter, "his plea to love Muslims and to "minister" to them comes across as sincere enough as do the sounds of his audience's reaction to it." ${ }^{126}$ Nettle JA suggested that on the whole, the appeals would prevent the seminar from inciting hatred in those audience members, even if Scot's presentation of Islam was imbalanced. ${ }^{127}$ Neave JA agreed, but noted that one ought not to see egregious statements about a religious group as negated by "expressions of feigned concern." 128

Nettle and Neave JJA found that the VCAT did not err materially in its approach to the s 11 defence, but considered it helpful to articulate the proper approach. It must first be determined whether the conduct was for a religious (or an academic, artistic or scientific) purpose. Secondly, the genuineness of this purpose must be assessed: is the stated purpose truly the purpose? Thirdly, the question is "whether the defendant engaged in the conduct reasonably and in good faith for the genuine religious purpose". Good faith requires the defendant's subjectively honest belief that the conduct was desirable to achieve the purpose. Reasonableness is objective, assessed according to the standards of the reasonable person. As Nettle JA states, this must reflect Australia's multicultural, pluralistic society:

[The reasonable person must] tolerate criticism by the adherents of one religion of the tenets of another religion; even though to some and perhaps to most in society such criticisms may appear ill-informed or misconceived or ignorant or otherwise hurtful to adherents of the latter faith. It is only when what is said is so ill-informed or misconceived or ignorant and so hurtful as to go beyond the bounds of what tolerance should accommodate that it may be regarded as unreasonable.

After this case, s 11(2) was added to clarify that "a religious purpose includes, but is not limited to, conveying or teaching a religion or proselytising".

125 At [176].

126 At [63].

${ }^{127}$ At [73].

128 At [196]. 
As the VCAT was found to have erred in applying s 8, the case was remitted to another judge to hear. Before the rehearing, the parties went to mediation and agreed to end the dispute. ${ }^{129}$

\section{Analysis}

Catch the Fire Ministries is unsettling. It forced the secular legal system to intervene in a dispute between two religious minority groups, after one took a literal translation of the other's sacred text as indicative of its teachings. Absurdly, this drew the VCAT into deciding whether a fundamentalist approach to another religion could be characterised as vilifying that religion. This shows the difficulties in applying these standards in practice. The parties' submissions muddied the legal issues for the VCAT - particularly in discussing whether Scot's literal interpretation was "true". Oddly, in the absence of a single authority on Islamic beliefs, the expert evidence included a Professor of Sociology, a Professor of Islamic Studies and, most perplexingly, a Catholic priest. Although the Court of Appeal reversed the VCAT decision, it took 5 years, and reportedly an excess of AUD $\$ 500,000$ to the parties before the case was settled. ${ }^{130}$

\section{The problems with Victoria's religious vilification law}

In light of Catch the Fire Ministries, a number of issues with religious vilification laws may be observed. It is pertinent that between 2002 and 2006, South Australia, Western Australia and New South Wales all considered implementing religious vilification provisions, but decided not to. ${ }^{131}$

\section{Vagueness}

Despite the Court of Appeal's attempts to clarify the proper use of Victoria's vilification law, the scope of s 8 remains vague. Nettle JA found that the balance of the presentation was irrelevant in assessing whether hatred was likely to be incited. Vilification laws only prohibit the incitement of hatred towards persons - hatred of beliefs is allowed. In contrast, Neave JA's approach focuses on the likelihood of inciting hatred in fact. Hatred

\footnotetext{
${ }^{129}$ Rex Tauati Ahdar "Religious Vilification: Confused Policy, Unsound Principle and Unfortunate Law" (2007) 26(2) UQLJ 293 at 305.

${ }^{130}$ Ahdar "Religious Vilification", above n 129, at 316; citing "Pastors settle "Vilifying Islam' Case" CBN News.com 25 June 2007.

131 Helen Pringle "Regulating Offence to the Godly: Blasphemy and the Future of Religious Vilification Laws" (2011) 34 UNSW Law Journal 316 at 323.
} 
may be fostered by attacking people's religious beliefs themselves, or by presenting an unbalanced or inaccurate account.

Neave JA's approach is attractively practical in addressing the harm of vilification. However, it goes to the core of freedom of expression principles. Thoughts, theories and religious beliefs - especially those that shape the worldview of its adherents - must be available for debate. Her approach draws attention to the artificiality of the distinction between attacking religious beliefs and attacking the religious person themselves. Further, Neave's acceptance that an unbalanced or inaccurate presentation may incite hatred is problematic. As Ahdar notes, an evangelist is not an "impartial purveyor of information akin to a responsible journalist... [a]nd it is surely not a secular court's role to vet religious presentations to ensure their accuracy or balance." ${ }^{\prime 132}$ It is unclear how s 8 will be applied in the future.

The scope of the s 11 defence also remains vague, although the 2006 amendment to clarify that proselytism was a legitimate religious purpose was helpful. Every decisionmaker will gauge what is "reasonable" in a multicultural society differently. Assessing whether the speaker honestly believed their speech was for a genuine religious purpose may also be problematic. In the case, the VCAT suggested that Scot's misrepresentation of Islamic beliefs indicated his lack of honest belief in his statements. "Misrepresentation" is a minefield where religion is concerned, particularly when a secular tribunal is asked to adjudicate the proper representation. ${ }^{133}$

It is indicative that even when the Court of Appeal expressly sought to clarify the workings of the Racial and Religious Tolerance Act, such fundamental issues remain. The proper place of freedom of expression within these provisions is contested, and will therefore depend on the view of the individual decision-maker.

\section{Chilling religious debate}

Religious vilification laws are likely to deter the vigorous discussion of religious beliefs, especially in light of expensive and protracted cases like Catch the Fire Ministries. Those discussing religious beliefs are likely to soften their arguments or avoid certain controversial topics, even where they would not actually fall within the scope of the vilification laws.

132 Ahdar "Religious Vilification", above n 129, at 312.

${ }^{133}$ Ahdar "Religious Vilification", above n 129, at 313. 
This is exacerbated by the inherent vagueness of term such as "hatred" and "contempt". It is impossible to explain in the abstract the difference between "inciting hatred" and merely "insulting". ${ }^{134}$ It must be a factual inquiry in each instance. Precedents are unlikely to offer meaningful guidance. ${ }^{135}$ Presenting an unduly critical or one-sided argument may contribute to a finding of vilification, as per Neave JA. Therefore, while the legislation purports to catch only the most harmful speech, its chilling effect goes beyond this. People are naturally risk-averse, and will self-regulate to avoid legal sanction. ${ }^{136}$

Moreover, it is clearly possible to incite hatred in simply practicing one's religion, if done so in an "unreasonable" manner. Amir Butler has noted: ${ }^{137}$

The problem is that as long as religions articulate a sense of what is right, they cannot avoid also defining - whether explicitly or implicitly - what is wrong. If we love God, then it requires us to hate idolatry. If we believe there is such a thing as goodness, then we must also recognise the presence of evil. If we believe our religion is the only way to Heaven, then we must also affirm that all other paths lead to Hell. If we believe our religion is true, then it requires us to believe others are false.

If these polarities are expressed in a certain way, they may well fall within the scope of vilification laws. Religious services, especially Christian ones, are usually open to the public. Even if the presentation is intended for believers, this does not prevent a complaint from being made. ${ }^{138}$ Public incitement is not restricted to picketing and protest. This has real implications for the freedom of religion.

\section{Divisiveness}

Amir Butler noted that during the Catch the Fire Ministries litigation, evangelical Christians were attending Islamic lectures, taking notes to be used as evidence. ${ }^{139}$ The adversarial system is a flawed tool in fostering tolerance. Parkinson makes the

134 Ahdar "Religious Vilification", above n 129, at 298.

135 Ahdar, "Religious Vilification", above n 129, at 298.

136 Parkinson, above n 96, at 10.

137 Amir Butler "Why I've changed my mind on Victoria's anti-vilification laws" (9 June 2004) Online Opinion <http://www.onlineopinion.com.au/>.

138 Parkinson, above n 96, at 9.

${ }^{139}$ Amir Butler "Why I've changed my mind on Victoria's anti-vilification laws" (9 June 2004) Online Opinion <http://www.onlineopinion.com.au>. See further Ahdar, above n 129. 
compelling point: vilification laws are divisive in allowing one religious group to be pitted against another in a legal forum. The problem is that these religious issues run deeper than what a court could possibly adjudicate. ${ }^{140}$ In support of this point, he cites another Victorian case, Judeh $v$ Jewish National Fund of Australia Inc, ${ }^{141}$ where a complaint was made regarding the logo of the Jewish National Fund. This incorporated the shaded outline of Israel, including the area of Palestine. The complainant unsuccessfully argued that publishing this logo incited hatred against Arab Palestinians on the grounds of their race.

Vilification laws arguably foster a "culture of offendedness". ${ }^{142}$ In arguing against Victoria's vilification laws, Zimmermann points to the tension between "multiculturalism" (grounded in diversity and group membership) and "democracy" (grounded in individualism and equal rights). ${ }^{143}$ Religious differences are not solely a matter of identity, but "uphold different values and produce rather different kinds of society." ${ }^{144}$ He points for instance to the human rights abuses and religious persecution in Muslim-majority countries. ${ }^{145}$ Democracy requires negotiation and compromise, and therefore requires certain "norms and conventions of behaviour". 146 The legal commitment to multiculturalism undermines democracy, he suggests, by allowing religions to exist as a "nation within a nation". ${ }^{147}$

Zimmermann's pro-Western, anti-Islamic approach arguably overstates the point, and undervalues the positive influences of diversity within democracy. Moreover, cultural diversity is a reality in most Western countries. That said, his point that vilification laws give legal support to social fragmentation is a strong one. The law must protect the freedom to discuss values and viewpoints within society. This may give rise to tension, especially considering that certain religious practices (wearing a veil, for instance) run counter to Western concepts of human rights. To exempt them from such critique may solidify practices - like society, religious beliefs are dynamic.

${ }^{140}$ Parkinson, above n 96, at 12-13.

${ }^{141}$ Judeh v Jewish National Fund of Australia Inc [2003] VCAT 1254.

142 Augusto Zimmermann "The Unconstitutionality of Religious Vilification Laws in Australia: Why Religious Vilification Laws Are Contrary to the Implied Freedom of Political Communication Affirmed in the Australian Constitution" (2013) BYU L Rev 457 at 488 .

${ }^{143}$ At 478.

${ }^{144}$ At 475.

145 At 476.

146 At 480.

${ }^{147}$ At 479. 
Cases like Catch the Fire Ministries and Judeh reflect the problematic uses for vilification laws. Although they purport to foster equality and prevent discrimination within society, these laws are called upon by groups whose sensitivities have been offended against. In practice, the distinction between seriously offending a religious group and inciting others to hatred against them may be illusory. Religious groups may use these laws to discourage public scrutiny of their beliefs. ${ }^{148}$ Considering that vilification laws lack clear guidance for behaviour, the threat of litigation may grant religious beliefs a level of immunity within public discourse.

\section{The English experience}

The English experience in passing the Racial and Religious Hatred Act 2006 (RRHA) further highlights the difficulties in gauging a law to address the harm of hate speech, while adequately protecting the freedom of expression. Controversial from the outset, this law criminalised the incitement of hatred. Unlike Victoria, there is no equivalent civil provision. Whereas the Victorian provision is simply phrased but vague in its application, leading to strange cases, the English law has been cast impossibly high.

\section{A The political and legislative context}

Passing the RRHA had greater political than practical significance. In the wake of the 11 September 2001 terrorist attacks, fears of anti-Muslim reprisals prompted a religious vilification provision to be suggested that same year. ${ }^{149}$ In the years following the attacks, organisations continued to demand legislation to protect innocent Muslims from those who associate them with terrorism. ${ }^{150}$

Yet, the legislation already in force was arguably sufficient to deal with extreme antiMuslim behaviour. It was more a matter of under-enforcement, rather than a lack of law to enforce. ${ }^{151}$ England already had a scheme of increased sentences for religiously aggravated offences. ${ }^{152}$ Section 5 of the Public Order Act 1986 provided that threatening,

\footnotetext{
148 Zimmermann, above n 145, at 471.

149 Religion and Anti-Terrorism, Crime and Security Bill 2001 (UK).

${ }^{150}$ Richard Kelly "The Racial and Religious Hatred Bill" House of Commons Library Research Paper 05/48 (16 June 2005) at 8.

${ }^{151}$ Kay Goodall "Incitement to Religious Hatred: All Talk and No Substance?" (2007) 70(1) MLR 89 at 91.

${ }^{152}$ Crime and Disorder Act 1998 (UK), ss 28-32.
} 
abusive or insulting conduct "within the hearing or sight of a person likely to be caused harassment, alarm or distress" constituted an offence. ${ }^{153}$ This had been successfully applied to religious vilification. For instance, Norwood was convicted under s 5 for displaying a poster depicting the World Trade Centre and the words "Islam out of Britain". ${ }^{154}$ Furthermore, s 18 of the Public Order Act prohibited the incitement of hatred based on "colour, race, nationality... or ethnic or national origins." Herein lay the perceived gap. Inciting hatred of "mono-ethnic" religions like Judaism and Sikhism was illegal, but adherents of world-wide religions such as Islam and Christianity were without protection. ${ }^{155}$ As Goodall said, "the problem was not the breadth of the gap but its significance." In particular, the British National Party consciously exploited this. Their incitement of hatred against Muslims was not actionable because it was phrased in religious, not racial, language. ${ }^{156}$ Therefore, ugly publications such as one describing Islam as a acronym for Intolerance, Slaughter, Looting, Arson and Molestation of Women, proliferated. ${ }^{157}$

\section{B Framing the provision}

Article 8 of the European Convention on Human Rights protects the freedom of expression in the United Kingdom. The initial Racial and Religious Hatred Bill was vigorously opposed as an unjustifiably broad incursion on free speech, especially considering the legislation already in force. The Bill simply amended the racial vilification provisions in the Public Order Act 1986 to include religious vilification also. It provided that: ${ }^{158}$

(1) A person who uses threatening, abusive or insulting words or behaviour, or displays any written material which is threatening, abusive or insulting, is guilty of an offence if -

(a) he intends thereby to stir up racial or religious hatred, or

(b) having regard to all the circumstances racial or religious hatred is likely to be stirred up thereby.

153 After the "Reform Section 5" campaign, this was amended in 2013 to remove "insulting" conduct from the scope of the offence.

${ }^{154}$ Norwood v DPP [2003] EWHC 1564 (Admin); 2003 WL 21491815 QBD (Admin Ct). ${ }^{155}$ Mandla v Dowell Lee [1983] 2 AC 548 (HL) at 565.

156 Goodall, above n 151, at 93-94.

157 Anthony Jeremy "Practical Implactions of the Enactment of the Racial and Religious Hatred Act 2006” (2007) 9 Ecc LJ 187 at 196.

${ }^{158}$ Racial and Religious Hatred Bill 2005 (UK). 
Religious hatred was defined broadly as "hatred against a group of persons defined by reference to religious belief or lack of religious belief." 159

This was unworkably broad, and would easily have caught legitimate or religious expression. As Goodall noted, a person could be liable if their "words, behaviour or material were likely to be seen or heard by any person in whom they were likely to stir up hatred." 160 No intention was necessary - a person only needed to be aware that their expression might have been threatening, abusive or insulting.

As the Bill progressed through Parliament, a number of changes were made to protect the freedom of expression. The religious hatred provision was given its own much narrower provision. For an offence to be committed, conduct must be "threatening", not merely "abusive or insulting", and the defendant must intend to stir up religious hatred. ${ }^{161}$ The Attorney-General must consent before proceedings can be instituted under the section. ${ }^{162}$ Significantly, s 29J was created expressly to protect the freedom of expression. This stated that: ${ }^{163}$

Nothing in this Part shall be read or given effect in a way which prohibits or restricts discussion, criticism or expressions of antipathy, dislike, ridicule, insult or abuse of particular religions or the beliefs or practices of their adherents, or of any other belief system or the beliefs or practices of its adherents, or proselytising or urging adherents of a different religion or belief system to cease practising their religion or belief system.

\section{Analysis}

Section 29J distinguishes between attacking the beliefs themselves and attacking the person. As passed, the RRHA protects the freedom to insult or abuse religious beliefs or practices, but criminalises the use of threatening words with the intention of stirring up religious hatred. The distinction between abuse, insults and threats is difficult to draw in the abstract, however it may be easier for the courts to draw in practice. However, in the absence of firm guidance, there will be a chilling effect on the critique of religious beliefs.

\footnotetext{
${ }^{159}$ Racial and Religious Hatred Bill 2005 (UK), s 17A; Racial and Religious Hatred Act 2006 (UK), s 29A.

${ }^{160}$ Goodall, above $\mathrm{n} 151$, at 89.

${ }^{161}$ Racial and Religious Hatred Act 2006 (UK), s 29B.

162 Section 29L.

163 Section 29J.
} 
Most importantly, the requirement to prove the intention to incite hatred is problematic, especially considering that the intention to merely abuse or insult will not be sufficient. ${ }^{164}$ Goodall argues that this makes the provision "almost unenforceable" without a defendant's confession. ${ }^{165}$ Indeed, at June 2013, there had only been one unsuccessful attempt at prosecution under the religious vilification provision. ${ }^{166}$

The RRHA is therefore largely symbolic; hoping to deter hatemongers simply due to its existence, and give legal weight to the assertion that stirring up hatred against religious persons or groups is not to be tolerated. ${ }^{167}$ Nash suggests that this may be a political manoeuvre, "compensating the Muslim community for the fact that young Muslim men are likely to be adversely affected by new legislation introduced to combat terrorism." 168

\section{Is there scope for an expansion of the Human Rights Act 1993?}

To conclude, this Part will return to the Oakes framework as articulated by Tipping $\mathrm{J},{ }^{169}$ to consider whether religious vilification laws are a demonstrably justified limitation on freedom of expression.

\section{A Does it serve a sufficiently important purpose to justify curtailing the freedom of expression?}

The ultimate goal is a tolerant, harmonious community that recognises the equality and human dignity of its members. Religious vilification laws purport to prevent the spread of hateful words that denigrate a group's equality and human dignity on the ground of their religious belief. As explored in Part V, hate speech causes real harm to its targets. It denigrates their self-esteem, and marginalises them within society. This affects social cohesion and targets' enjoyment of civil and political rights.

164 Goodall, above n 151, at 112.

165 At 113.

${ }^{166}$ UK Law Commission Hate Crime: the case for extending the existing offences Consultation Paper No 213 (2013) at 2.107; see also UK Law Commission Hate Crime: Should the Current Offences be Extended? Law Com No 348 (May 2014).

${ }^{167}$ David Nash and Chara Baklis 'Incitement to Religious Hatred and the 'Symbolic': How Will the Racial and Religious Hatred Act 2006 Work?" (2007) 28 Liverpool Law Review 349 at 366.

168 At 365.

${ }^{169}$ Hansen $v$ R, above $\mathrm{n} 25$, at [104]. 


\section{B Is it rationally connected with this purpose?}

These laws only prohibit fostering hatred in others, but not direct expressions of hatred. This supports the equality and dignity of religious people, in that it is illegal to spread these messages of hate. The hope is that left isolated, poisonous thoughts will fade away. Therefore, a rational connection exists.

\section{$C$ Does it impair the freedom of expression no more than is reasonably necessary for sufficient achievement of its purpose?}

As established in Part VI, religious vilification laws only impinge narrowly upon the freedom of expression, due to their high threshold. The issues they pose are primarily academic, for instance, in limiting democratic legitimacy and the search for truth. In reality however, these laws are intended to merely regulate form rather than content. Similar ideas may be expressed in more temperate terms.

\section{Difficulties in framing a law}

Yet the effect of these laws will be wider than their strict legal intention. The chilling effect will be broader than the strictly illegal speech, especially because no bright line can be drawn between vilifying and non-vilifying conduct. Even with the best efforts of the Victorian Court of Appeal, the correct balance between the freedom of expression and the harm is difficult to state.

On the other hand, England's Act has been tightened so far that it is barely enforceable. Furthermore, in creating the law, there is a risk that the harm of hate speech will be exacerbated. The legal forum may attract attention to the harmful views, making hatemongers into martyrs. ${ }^{170}$ Furthermore, England's requirement for Attorney-General consent draws the government into these disputes. If the government declines to act, the targets may feel more alienated than they would have otherwise. Richard Winfield suggested that the Danish cartoons would have caused less controversy had there not been vilification laws in place. The Muslim targets viewed the government's decision not to prosecute as a further hostile act. ${ }^{171}$

\footnotetext{
${ }^{170}$ Nash and Baklis, above n 167, at 339.

${ }^{171}$ Richard N Winfield “An Editorial Controversy Metasizing Denmark's Hate Speech Laws" in Marilyn Greene (ed) It's a Crime: How Insult Laws Stifle Press Freedom (World Press Freedom Committee, Denmark, 2006) 301 at 303.
} 
Arguably, the only language chilled would be nasty and pointed speech that causes harm to its targets. There is little social utility in allowing people to hurt others based on their deeply-held beliefs. Even so, the freedom of expression goes to the core of our democratic system. We do not want to encourage this "culture of offendedness" whereby the legal system can be readily turned to to remedy intangible and unquantifiable harms.

\section{Will it sufficiently achieve the purpose?}

A major problem is that the true problem is difficult to legislate for. Although they certainly cause harm, public hate rallies and extreme leaflets are not the primary contributors to the discrimination and marginalisation of certain racial minorities. The discourse that casts these people as the "other" is insidious. Nash and Baklis state this admirably: ${ }^{172}$

racist views and behaviour are the result of being exposed to racist opinions at home and these opinions being accepted within a particular community rather than being the result of reading racist literature or attending a racist rally. In fact, trying to stop racist attacks through an incitement to racial hatred law is to misunderstand the very nature of racism which is not necessarily about hating a particular race but is a complicated inter-play between social conditioning and poverty. The same would apply to any attempt to stop religious hatred.

The value of these laws lies in their symbolism, especially if they are not often utilised, as with the HRA racial vilification provisions. Matsuda suggests that part of the sting from hate speech is the government's failure to support the targets. ${ }^{173}$ If nothing else, religious vilification legislation recognises the harm to an individual's identity that may occur from hate speech.

\section{Alternatives to legislation}

Education can buffer against the societal harm better than empowering offended parties to take their claim to court. This is New Zealand's current approach, which appears to be relatively successful in advocating for minorities and giving them a voice. For instance, in 2005 the Office of Ethnic Affairs, alongside the Federation of Islamic Associations of New Zealand initiated a 'Building Bridges' programme to strengthen the connections between the Muslim community and wider society. Its 2013 report was positive

${ }^{172}$ Nash and Baklis, above n 167, at 359-60.

${ }^{173}$ Matsuda, above n 38, at 2338. 
regarding the sense of Muslim belonging, and noted a more balanced portrayal of Muslims in the media. ${ }^{174}$

Furthermore, each year the Human Rights Commission runs a Religious Diversity Forum, and interfaith forums are encouraged. ${ }^{175}$ Furthermore, the significance of the media in perpetuating damaging stereotypes has been increasingly acknowledged - in 2013, the Religious Diversity Forum focused on religion in the media. The law is a blunt tool, and is not the most constructive option here.

\section{$D$ Is it in due proportion to the importance of the objective?}

The importance of the freedom of expression and the importance of avoiding the harm caused to targets of hate speech must also be seen alongside the significance of the freedom of religion. As Catch the Fire Ministries indicates, religious vilification laws can suppress the power to proselytise. If New Zealand were to expand their law to religious vilification, it would need to create a defence for legitimate religious expression also.

This is a key distinction between racial and religious vilification laws. Racial vilification laws are more easily justified. As Parkinson observes, "there is no similar important interest to protect if vilification laws have a chilling effect on racial speech that falls short of vilification." ${ }^{176}$ Moreover, unlike religion, races do not have different standards for what might constitute offence. Certain religions are less tolerant than others. ${ }^{177}$ It is also necessary to define what a religion is for the purpose of the law. ${ }^{178}$ While some have noted that it would be just as valid to delete the racial vilification law as to extend it to religion, this is not necessarily true. ${ }^{179}$ Religions are problematic as they defy categorisation. They are both a matter of identity and a body of values and ideas.

The freedom of religion and freedom of expression are best served by minimalist government intervention.

174 The Office of Ethnic Affairs Building Bridges (Office of Ethnic Affairs, Wellington, 2013).

${ }^{175}$ New Zealand Human Rights Commission Report to the United Nations Committee on the Elimination of Racial Discrimination (July 2012).

176 Parkinson, above n 96, at 15.

177 Barendt, above n 52, at 191.

178 Barendt, above $\mathrm{n} 52$, at 191.

${ }^{179}$ Hare, above n 30, at 533. 


\section{Conclusion}

Religious vilification laws are very interesting in light of the broad freedom of expression guaranteed in New Zealand. With the current minimalist approach to enforcing ss 61 and 131 of the HRA, it is unlikely that there would be the necessary political impetus to extend this to religious vilification. Moreover, when seen in light of the freedom of expression and freedom of religion, it gives rise to a number of issues. Education and community support is a far preferable option here. 


\section{Bibliography}

\section{A Cases}

$1 \quad$ New Zealand

Hansen v R [2007] NZSC 7, [2007] 3 NZLR 1.

Hosking v Runting [2004] NZCA 34; [2005] 1 NZLR 1.

King-Ansell v Police [1979] 2 NZLR 531 (CA).

Living Word Distributors Ltd v Human Rights Action Group (Wellington) [2000] 3 NZLR 570 (CA).

$R$ v Morse [2011] NZSC 45, (2011) 25 CRNZ 174.

\section{United States}

Abrams v US (1919) 250 US 616 at 630-1.

Brandenburg $v$ Ohio (1969) 395 US 444.

Cohen v California (1971) 405 US 15.

\section{United Kingdom}

Norwood v DPP [2003] EWHC 1564 (Admin); 2003 WL 21491815 QBD (Admin Ct).

Mandla v Dowell Lee [1983] 2 AC 548 (HL).

\section{Canada}

$R v$ Oakes [1986] 1 SCR 103.

$R$ v Keegstra [1990] 3 SCR 697.

\section{Australia}

Bropho v Human Rights and Equal Opportunity Commission [2004] FCAFC 16.

Catch the Fire Ministries Inc v Islamic Council of Victoria Inc [2006] VSCA 284.

Islamic Council of Victoria Inc v Catch the Fire Ministries Inc [2004] VCAT 2510.

Islamic Council of Victoria v Catch the Fire Ministries Inc [2005] VCAT 1159.

Judeh v Jewish National Fund of Australia Inc [2003] VCAT 1254.

Nationwide News Pty Ltd v Wills (1992) 177 CLR 1. 
6 European Court of Human Rights

Handyside v UK [1976] ECHR 5 (ECHR).

\section{B Legislation}

$7 \quad$ New Zealand

Human Rights Act 1993.

\section{Australia}

Anti-Discrimination Act 1998 (Tas).

Anti-Discrimination Amendment Act 2001 (Qld).

Racial and Religious Tolerance Act 2001 (Vic), s 8(1).

\section{United Kingdom}

Crime and Disorder Act 1998 (UK).

Racial and Religious Hatred Bill 2005 (UK).

Racial and Religious Hatred Act 2006 (UK).

Religion and Anti-Terrorism, Crime and Security Bill 2001 (UK).

10 Denmark

Danish Criminal Code, s 266.

\section{International treaties}

International Convention on the Elimination of All Forms of Racial Discrimination 660 UNTS 195 (opened for signature 21 December 1965, entered into force 4 January 1969).

International Covenant on Civil and Political Rights 999 UNTS 171 (opened for signature 16 December 1966, entered into force 23 March 1976).

\section{Books and Chapters in Books}

Eric Barendt Freedom of Speech (2ed, Oxford University Press, Oxford, 2005). 
Kevin Boyle "Overview of a Dilemma" in Sandra Coliver (ed) Striking a Balance: Hate Speech, Freedom of Expression and Non-discrimination (Human Rights Centre, University of Essex, Colchester, 1992).

Dr Andrew Butler and James Shaerf "Limiting Fundamental Rights: how on earth is s 5 supposed to work in practice?" in NZLS Using the Bill of Rights in Civil and Criminal Litigation (Continuing Legal Education NZLS, Wellington, 2008).

Ian Cram "The Danish Cartoons, Offensive Expression, and Democratic Legitimacy" in Ivan Hare and James Weinstein Extreme Speech and Democracy (Oxford University Press, Oxford, 2009) 311.

Laraine R Fergenson “Group Defamation: From Language to Thought to Action” in Monroe H. Freedman and Eric M. Freedman (eds) Group Defamation and Freedom of Speech: The Relationship between Language and Violence (Greenwood Press, Westport, 1995) 71.

Stanley Fish There's No Such Thing as Free Speech (Oxford University Press, Oxford, 1994).

Claudia Geiringer "Shaping the interpretation of Statutes: where are we now in the s 6 debate?" in NZLS Using the Bill of Rights in Civil and Criminal Litigation (Continuing Legal Education NZLS, Wellington, 2008).

Human Rights Commission Religious Diversity in Aotearoa New Zealand: Statement on Religious Diversity (2 ${ }^{\text {nd }}$ ed, August 2009).

Grant Huscroft "Defamation, Racial Disharmony, and Freedom of Expression" in Grant Huscroft and Paul Rishworth (eds) Rights and Freedoms (Brooker's Ltd, Wellington, 1995) 171.

Matthias Mahlmann "Free Speech and the Rights of Religion” in András Sája (ed) Censorial Sensitivities: free speech and religion in a fundamentalist world (Eleven International Publishers, Portland, 2007) 41.

John Stuart Mill On Liberty (1859) The University of Adelaide Library <https://ebooks.adelaide.edu.au/m/mill/john_stuart/m645o/>.

Robert Post "Religion and Freedom of Speech: Portraits of Muhammad" in András Sája (ed) Censorial Sensitivities: free speech and religion in a fundamentalist world (Eleven International Publishers, Portland, 2007) 329. 
Nadine Strossen "Liberty and Equality: Complementary, Not Competing, Constitutional Limits" in Grant Huscroft and Paul Rishworth (eds) Litigating Rights: perspectives from domestic and international law (Hart Publishing, Oxford, 2002) 149.

James Weinstein "Extreme Speech, Public Order, and Democracy: Lessons from The Masses" in Ivan Hare and James Weinstein (eds) Extreme Speech and Democracy (Oxford University Press, Oxford, 2009) 23.

Catherine Lane West-Newman "Reading Hate Speech from the Bottom in Aotearoa: Subjectivity, Empathy, Cultural Difference” (2001) Wai L Rev 231.

Richard N Winfield “An Editorial Controversy Metasizing Denmark's Hate Speech Laws" in Marilyn Greene (ed) It's a Crime: How Insult Laws Stifle Press Freedom (World Press Freedom Committee, Denmark, 2006) 301.

\section{E Journal articles}

Rex J Ahdar "Reflections on the Path of Religion-State Relations in New Zealand" (2006) 3 BYU Law Review 619 at 623.

Rex Tauati Ahdar "Religious Vilification: Confused Policy, Unsound Principle and Unfortunate Law" (2007) 26(2) UQLJ 293.

Eric Barendt "Freedom of Expression in the United Kingdom Under the Human Rights Act 1998” (2009) 84 Ind LJ 851.

Antoine Buyse "Dangerous Expressions: The ECHR, Violence and Free Speech" (2014) 63(2) International and Comparative Law Quarterly 491.

Anthony Ellis "Offense and the Liberal Conception of the Law" (1984) 13(1) Philosophy \& Public Affairs 3.

Richard Delgado and David H. Yun "Pressure Valves and Bloodied Chickens: An Analysis of Paternalistic Objections to Hate Speech Regulation" (1994) 82 CLR 871.

Malcolm D Evans "From Cartoons to Crucifixes: current controversies concerning the freedom of religion and the freedom of expression before the European Court of Human Rights" (2010) 26 Journal of Law \& Religion 345.

Klaus Fiedler "Language: A Toolbox for Sharing and Influencing Social Reality" (2008) 3 Perspectives on Psychological Science 38. 
Andrew Geddis "Free Speech Martyrs or Unreasonable Threats to Social Peace? "Insulting" Expression and Section 5 of the Public Order Act 1986" [2004] PL 853. Kay Goodall “Incitement to Religious Hatred: All Talk and No Substance?” (2007) 70(1) MLR 89.

Ivan Hare "Crosses, Crescents and Sacred Cows: Criminalising Incitement to Religious Hatred" [2006] PL 521.

Joel Harrison "Truth, Civility, and Religious Battlegrounds: The Contest Between Religious Vilification Laws and Freedom of Expression” (2006) 12 Auckland U. L. Rev. 71.

Anthony Jeremy "Practical Implactions of the Enactment of the Racial and Religious Hatred Act 2006" (2007) 9 Ecc LJ 187.

Erich Kolig and Nahid Kabir "Not Friend, Not Foe: The Rocky Road of Enfranchisement of Muslims into Multicultural Nationhood in Australia and New Zealand" (2008) 26(3) Immigrants \& Minorities: Historical Studies in Ethnicity, Migration and Diaspora 266.

Kathleen Mahoney "Hate Speech: Affirmation or Contradiction of Freedom of Expression" (1996) 3 U Ill L Rev 789.

Mari J. Matsuda "Public Response to Racist Speech: Considering the Victim's Story" (1988-1989) 87 Mich L Rev 2320.

Alexander Meiklejohn "The First Amendment is an Absolute" (1961) Supreme Court Review 245.

David Nash and Chara Baklis 'Incitement to Religious Hatred and the 'Symbolic': How Will the Racial and Religious Hatred Act 2006 Work?” (2007) 28 Liverpool Law Review 349.

Patrick Parkinson "Enforcing Tolerance: Religious Vilification Laws in Australia" (Paper presented at the Eleventh Annual International Law and Religion Symposium, "Religion in the Public Sphere: Challenges and Opportunities", Provo, Utah, 3-6 October 2004).

Robert Post "Democracy and Equality" (2006) 603(1) ANNALS of the Am. Acad, Pol. \& Soc. Sci. 24. 
Scott Poynting and Barbara Perry "Climates of Hate: Media and State Inspired Vicitimisation of Muslims in Canada and Australia since 9/11" (2007) 19(2) Current Issues in Criminal Justice 151.

Helen Pringle "Regulating Offence to the Godly: Blasphemy and the Future of Religious Vilification Laws” (2011) 34 UNSW Law Journal 316.

Paul Rishworth "The Religion Clauses of the New Zealand Bill of Rights" (2007) NZLR 631.

David W. Shoemaker "'Dirty Words' and the Offense Principle" (2000) 19 Law and Philosophy 545.

Jean Stefancic and Richard Delgado "A Shifting Balance: Freedom of Expression and Hate-Speech Restriction” (1993) 78 Iowa L Rev 737.

"The James McCormick Mitchell Lecture: Language as Violence v. Freedom of Expression: Canadian and American Perspectives on Group Defamation” (1988/89) 37 Buff L Rev 337 at 359.

Simon Thompson "Freedom of expression and hatred of religion" (2012) 12 Ethnicities 215.

Alfred de Zayas and Áurea Roldán Martín "Freedom of Opinion and Freedom of

Expression: Reflections on General Comment No 34 of the UN Human Rights Committee" (2009) 59 NILR 425.

Aleardo Zanghellini "Jurisprudential Foundations for Anti-Vilification Laws: The Relevance of Speech Act and Foucauldian Theory" (2003) 27 Melb U L Rev 458.

Augusto Zimmermann "The Unconstitutionality of Religious Vilification Laws in Australia: Why Religious Vilification Laws Are Contrary to the Implied Freedom of Political Communication Affirmed in the Australian Constitution" (2013) BYU L Rev 457.

\section{F Internet material}

2013 QuickStats About Culture and Identity" (April 2013) Statistics New Zealand $<$ http://www.stats.govt.nz>.

Kurt Bayer "NZ First MP: Ban Muslims from flights" (12 February 2013) New Zealand Herald <www.nzherald.co.nz>. 
Amir Butler "Why I've changed my mind on Victoria's anti-vilification laws" (9 June 2004) Online Opinion <http://www.onlineopinion.com.au/>.

Errol Kiong and Jon Stokes "NZ embassy alert over cartoon row" (6 February 2006) New Zealand Herald <http://www.nzherald.co.nz>.

\section{G Government material}

\section{New Zealand}

New Zealand Human Rights Commission Report to the United Nations Committee on the Elimination of Racial Discrimination (July 2012).

The Office of Ethnic Affairs Building Bridges (Office of Ethnic Affairs, Wellington, 2013).

\section{United Kingdom}

Richard Kelly "The Racial and Religious Hatred Bill” House of Commons Library Research Paper 05/48 (16 June 2005).

UK Law Commission Hate Crime: Should the Current Offences be Extended? Law Com No 348 (May 2014).

UK Law Commission Hate Crime: the case for extending the existing offences Consultation Paper No 213 (2013). 